\title{
Geochronology of Cenozoic Rocks in the Bodie Hills, California and Nevada
}

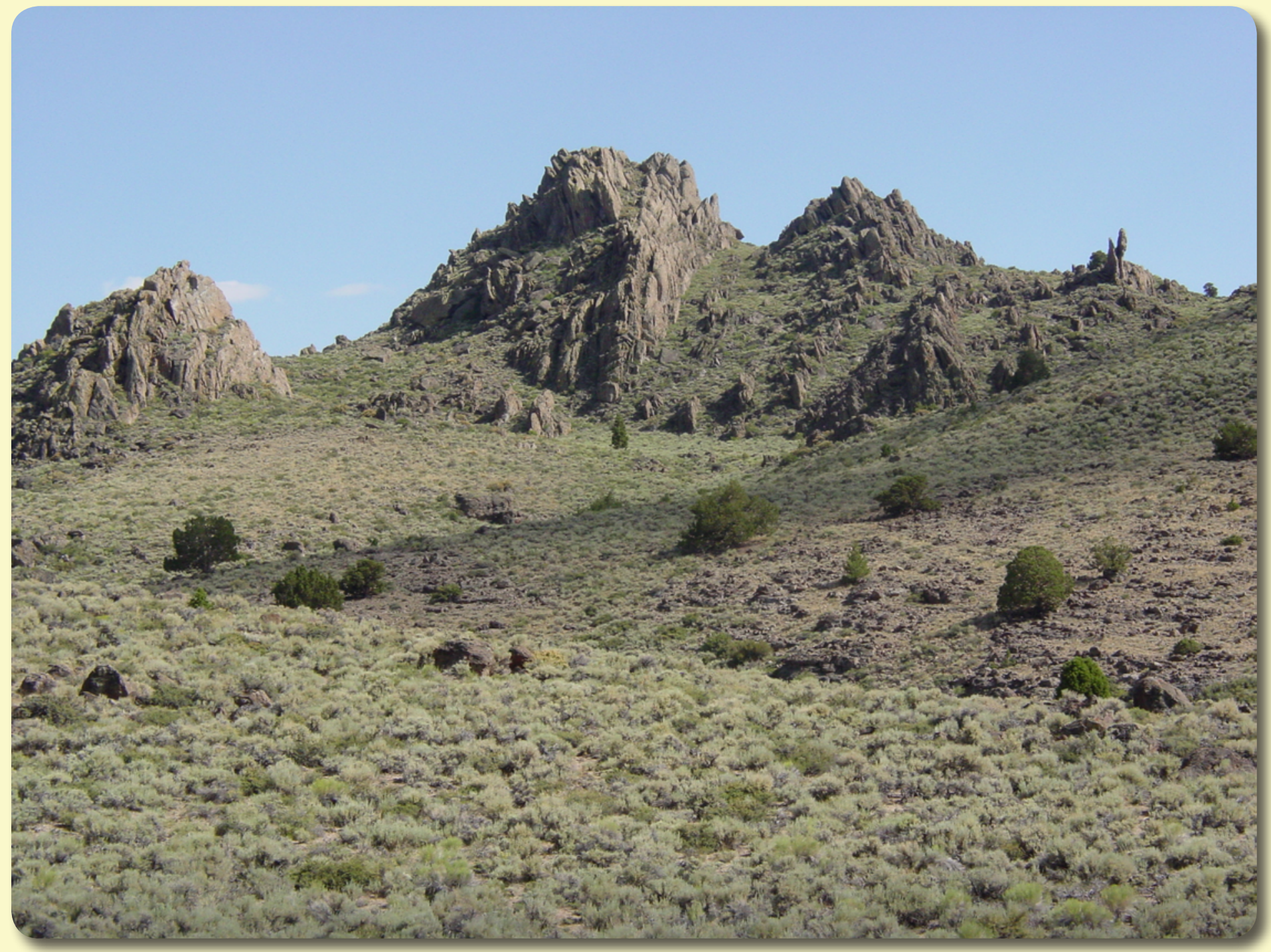

Data Series 916

U.S. Department of the Interior

U.S. Geological Survey 
Cover. Steeply flow-banded lava dome, trachyandesite of Willow Springs, east of Warm Spring in the Bodie Hills, California. 


\section{Geochronology of Cenozoic Rocks in the Bodie Hills, California and Nevada}

By Robert J. Fleck, Edward A. du Bray, David A. John, Peter G. Vikre, Michael A.

Cosca, Lawrence W. Snee, and Stephen E. Box

Data Series 916 


\title{
U.S. Department of the Interior SALLY JEWELL, Secretary
}

\section{U.S. Geological Survey \\ Suzette M. Kimball, Acting Director}

\author{
U.S. Geological Survey, Reston, Virginia: 2015
}

For more information on the USGS - the Federal source for science about the Earth, its natural and living resources, natural hazards, and the environment—visit http://www.usgs.gov or call 1-888-ASK-USGS.

For an overview of USGS information products, including maps, imagery, and publications, visit http://www.usgs.gov/pubprod/.

Any use of trade, firm, or product names is for descriptive purposes only and does not imply endorsement by the U.S. Government.

Although this information product, for the most part, is in the public domain, it also may contain copyrighted materials as noted in the text. Permission to reproduce copyrighted items must be secured from the copyright owner.

Suggested citation:

Fleck, R.J., du Bray, E.A., John, D.A., Vikre, P.G., Cosca, M.A., Snee, L.W., and Box, S.E., 2015, Geochronology of Cenozoic rocks in the Bodie Hills, California and Nevada: U.S. Geological Survey Data Series 916, 26 p., http://dx.doi.org/10.3133/ds916.

ISSN 2327-638X (online) 


\section{Contents}

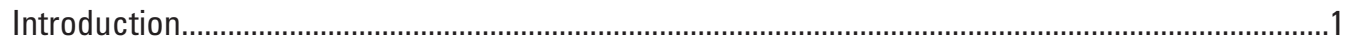

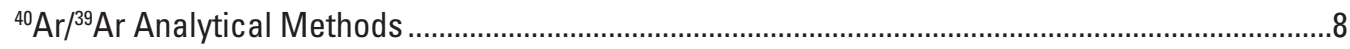

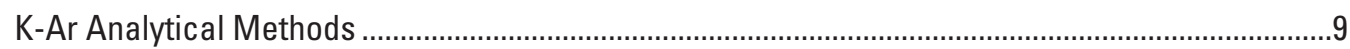

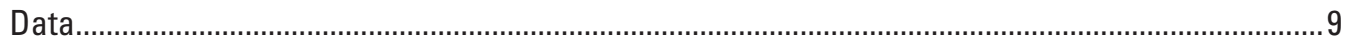

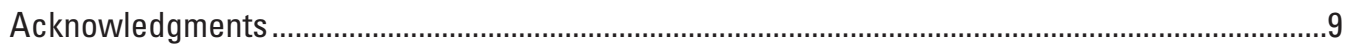

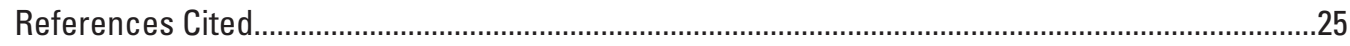

\section{Figures}

1. Map showing location of and major physiographic features near the Bodie Hills

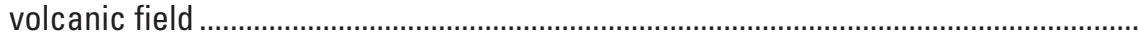

2. Locations of samples with ${ }^{40} \mathrm{Ar} /{ }^{39} \mathrm{Ar}$ age determinations shown on a simplified geologic map of the Bodie Hills volcanic field, California and Nevada .....................10

3. Locations of samples with K-Ar age determinations shown on a simplified geologic map of the Bodie Hills volcanic field, California and Nevada ....................................12

\section{Tables}

1. Map location numbers for ${ }^{40} \mathrm{Ar} /{ }^{39} \mathrm{Ar}$ geochronology samples from the Bodie Hills volcanic field, California and Nevada

2. Map location numbers for K-Ar geochronology samples from the Bodie Hills volcanic field, California and Nevada

3. Summary compilation of geochronologic data for samples of the Bodie Hills volcanic field, California and Nevada

\section{Appendixes}

[Available for download at http://pubs.usgs.gov/ds/916/]

1. Analytical results of $\mathrm{CO}_{2}$-laser-fusion and resistance-furnace incremental heating ${ }^{40} \mathrm{Ar} /{ }^{39} \mathrm{Ar}$ experiments (Menlo Park lab) for samples of the Bodie Hills volcanic field

2. Analytical results of furnace incremental heating ${ }^{40} \mathrm{Ar} /{ }^{39} \mathrm{Ar}$ experiments (Denver lab, Snee) for samples of the Bodie Hills volcanic field

3. Analytical results of $\mathrm{CO}_{2}$-laser incremental heating ${ }^{40} \mathrm{Ar} /{ }^{39} \mathrm{Ar}$ experiments (Denver lab, Cosca) for samples of the Bodie Hills volcanic field 



\title{
Geochronology of Cenozoic Rocks in the Bodie Hills, California and Nevada
}

\author{
By Robert J. Fleck, Edward A. du Bray, David A. John, Peter G. Vikre, Michael A. Cosca, Lawrence W. Snee, \\ and Stephen E. Box
}

\section{Introduction}

The purpose of this report is to present geochronologic data for unaltered volcanic rocks, hydrothermally altered volcanic rocks, and mineral deposits of the Miocene Bodie Hills and Pliocene to Pleistocene Aurora volcanic fields of east-central California and west-central Nevada. Most of the data presented here were derived from samples collected between 2000-13, but some of the geochronologic data, compiled from a variety of sources, pertain to samples collected during prior investigations. New data presented here (tables 1 and 2; Appendixes 1-3) were acquired in three U.S. Geological Survey (USGS) ${ }^{40} \mathrm{Ar} /{ }^{39} \mathrm{Ar}$ labs by three different geochronologists: Robert J. Fleck (Menlo Park, CA), Lawrence W. Snee (Denver, CO), and Michael A. Cosca (Denver, CO). Analytical methods and data derived from each of these labs are presented separately.

The middle to late Miocene Bodie Hills volcanic field (BHVF) is a large $\left(>700 \mathrm{~km}^{2}\right)$, long-lived ( $\sim 9$ million years [m.y.]), episodic eruptive complex (John and others, 2012) in the southern segment of the ancestral Cascades arc (du Bray and others, written commun., 2015) north of Mono Lake and east of Bridgeport, California (fig. 1). The field is near the west edge of the Walker Lane and the northwest edge of the Mina deflection where structures related to these shear zones may have localized magmatism. The Walker Lane (fig. 1) is a broad, northwest-striking zone of right-lateral shear that accommodates right-lateral motion between the Pacific and North America plates; the Mina deflection constitutes a $60-\mathrm{km}$-long right step in the Walker Lane (Faulds and Henry, 2008; Oldow, 1992, 2003; Stewart, 1988). The Bodie Hills volcanic field includes at least 31 volcanic rock units erupted from 21 significant volcanic eruptive centers.

Four trachyandesite stratovolcanoes developed along the margins of the volcanic field and numerous silicic trachyandesite to rhyolite flow dome complexes erupted more centrally. Volcanism in the Bodie Hills volcanic field peaked at two periods, $\sim 15.0$ to 12.6 million years before present (Ma) and $\sim 9.9$ to $8.0 \mathrm{Ma}$, which were dominated by emplacement of large stratovolcanoes and large silicic trachyandesite-dacite lava domes, respectively. A final period of small-volume silicic dome emplacement began in the western part of the volcanic field at $\sim 6 \mathrm{Ma}$ and culminated at $\sim 5.5 \mathrm{Ma}$ (John and others, 2012).
Compositions of Bodie Hills volcanic rocks vary from $\sim 50$ to 78 weight percent $\mathrm{SiO}_{2}$, although rocks with $<55$ weight percent $\mathrm{SiO}_{2}$ are rare. Rock compositions form a high-potassium $(\mathrm{K})$ calc-alkaline series with pronounced negative titanium-phosphorus-niobium-tantalum anomalies and high barium/niobium, barium/tantalum, and lanthanum/ niobium typical of subduction-related continental margin arcs (Gill, 1981). Most rocks are porphyritic and commonly contain 15-35 volume percent phenocrysts of plagioclase, pyroxene, and hornblende \pm biotite. Although the oldest eruptive centers have the most mafic compositions, erupted rock compositions oscillated between mafic and intermediate to felsic compositions through time. Following a brief hiatus in volcanism, post subduction rocks of the 2 .9- to $0.1-\mathrm{Ma}$, bimodal, high-K Aurora volcanic field were erupted onto the Bodie Hills volcanic field. Volcanism in the Bodie Hills volcanic field persisted until 8 Ma without apparent changes in rock composition or style of eruption despite the transition from subduction of the Farallon plate beneath the west coast of North America to establishment of a transform plate margin at $\sim 10 \mathrm{Ma}$ (John and others, 2012).

The eastern and southeastern parts of the Bodie Hills volcanic field and Miocene sedimentary rocks on the southern edge of Fletcher Valley are unconformably overlain by Pliocene to late Pleistocene ( 3.9 to $0.1 \mathrm{Ma}$ ) rocks of the Aurora volcanic field (Gilbert and others, 1968; Al-Rawi, 1969; Chesterman and Gray, 1975; Kleinhampl and others, 1975; Lange and others, 1993; Lange and Carmichael, 1996; Kingdon and others 2013). The field covers $\sim 325 \mathrm{~km}^{2}$ and includes many well-preserved volcanic centers. These centers consist of monogenetic lava and cinder cones, valley-filling lava flows, shield volcanoes, and lava domes. Compositions of the Aurora volcanic field rocks are bimodally distributed and consist principally of trachyandesite and trachydacite to high-silica rhyolite.

Numerous hydrothermal systems were operative in the Bodie Hills during the Miocene (Vikre and others, in press). Structurally focused hydrothermal systems formed large epithermal gold-silver vein deposits in the Bodie and Aurora mining districts that are temporally and spatially related to intermediate- to silicic-composition dome complexes (John and others, 2012). 
Table 1. Map location numbers for ${ }^{40} \mathrm{Ar} /{ }^{39} \mathrm{Ar}$ geochronology samples from the Bodie Hills volcanic field, California and Nevada.

\begin{tabular}{|c|c|c|c|c|c|}
\hline $\begin{array}{c}\text { Map } \\
\text { location } \\
\text { number }\end{array}$ & Sample number & Latitude & Longitude & Unit; alteration zone; or mining district & $\begin{array}{c}\text { Appendix } \\
\text { number }\end{array}$ \\
\hline 1 & 098-12B & 38.38762 & -119.18139 & Trachyandesite of Masonic & 1 \\
\hline 2 & 098-12A & 38.35923 & -119.19917 & Eureka Valley Tuff & 1 \\
\hline 3 & MAS10-72 & 38.40189 & -119.13718 & Trachyandesite of Masonic Gulch & 1 \\
\hline 4 & RW08-1 & 38.41123 & -119.12414 & Alteration: Red Wash-East Walker River alteration zone & 1 \\
\hline 5 & MAS10-73 & 38.39643 & -119.13470 & Trachyandesite of Masonic Gulch & 1 \\
\hline 6 & 098-12D & 38.39951 & -119.11939 & Trachyandesite of Masonic & 1 \\
\hline 7 & MAS10-55 & 38.41419 & -119.10259 & Alteration: Red Wash-East Walker River alteration zone & 1 \\
\hline 8 & 098-12E & 38.39143 & -119.12397 & Trachyandesite of Masonic Gulch & 1 \\
\hline 9 & MAS10-75 & 38.39169 & -119.11549 & Trachyandesite of Masonic Gulch & 1 \\
\hline 10 & 07-BA-38 & 38.36049 & -119.14502 & Andesite of Lakeview Spring & 1 \\
\hline 11 & MAS07-1A & 38.34992 & -119.14832 & Alteration: Masonic mining district, Chemung mine & 1 \\
\hline 12 & MAS12-10 \#1 & 38.33716 & -119.16013 & Alteration: Masonic mining district, Success mine & 1 \\
\hline 13 & MAS12-10 \#2 & 38.33716 & -119.16013 & Alteration: Masonic mining district, Success mine & 1 \\
\hline 14 & MAS10-76 & 38.38169 & -119.11534 & Trachyandesite of Masonic, plug & 1 \\
\hline 15 & MAS09-1A & 38.35847 & -119.13824 & Alteration: Masonic mining district, Red Rock mine & 1 \\
\hline 16 & 12-BA-20 & 38.33410 & -119.15949 & Trachyandesite of Masonic & 1 \\
\hline 17 & MAS09-1 & 38.35783 & -119.13268 & Alteration: Masonic mining district, Red Rock mine & 1 \\
\hline 18 & $098-12 \mathrm{~F}$ & 38.37542 & -119.11418 & Trachyandesite of Masonic & 1 \\
\hline 19 & MAS07-3 & 38.35968 & -119.12682 & Alteration: Masonic mining district, Sarita mine & 1 \\
\hline 20 & $07-\mathrm{BA}-40$ & 38.36544 & -119.11607 & Alteration: Masonic mining district, Pittsburg-Liberty mine & 1 \\
\hline 21 & $088-22 \mathrm{~A}$ & 38.36731 & -119.10727 & Alteration: Masonic mining district, Maybelle mine & 1 \\
\hline 22 & 10-BA-15 & 38.34130 & -119.11570 & Trachyandesite of Masonic & 1 \\
\hline 23 & 10-BA-13 & 38.35154 & -119.10419 & Trachyandesite of Masonic & 1 \\
\hline 24 & 088-22B & 38.37937 & -119.07802 & Trachyandesite of Masonic & 1 \\
\hline 25 & MAS11-2B & 38.36064 & -119.08681 & Alteration: Masonic mining district, Perini mine & 1 \\
\hline 26 & MAS11-1 & 38.36041 & -119.08369 & Alteration: Masonic mining district, Perini mine & 1 \\
\hline 27 & $11-\mathrm{BA}-40$ & 38.41155 & -119.01907 & Trachydacite of Rough Creek & 1 \\
\hline 28 & $09-\mathrm{BA}-7$ & 38.33786 & -119.08727 & Trachyandesite of Masonic & 1 \\
\hline 29 & 12-BA-9 & 38.33679 & -119.07378 & Trachydacite of East Canyon & 1 \\
\hline 30 & 08SB038 & 38.40828 & -118.97383 & Trachyandesite of Del Monte & 1 \\
\hline 31 & 10-BA-29 & 38.36466 & -119.01452 & Trachydacite of Rough Creek & 1 \\
\hline 32 & 10-BA-9 & 38.35278 & -119.02068 & Trachyandesite of Masonic, plug & 1 \\
\hline 33 & $6-289-2 / 45 / \mathrm{DD} 72$ & 38.3729 & -118.9993 & Eureka Valley Tuff & 2 \\
\hline 34 & $10-B A-62$ & 38.36327 & -119.00635 & Tephra in sedimentary rocks of Fletcher Valley & 1 \\
\hline 35 & $10-B A-6$ & 38.33375 & -119.02470 & Trachydacite of Rough Creek & 1 \\
\hline 36 & 10-BA-5 & 38.33945 & -118.99699 & Pyroxene rhyolite & 1 \\
\hline 37 & $11-\mathrm{BA}-41$ & 38.35057 & -118.98085 & Trachyandesite of Del Monte & 1 \\
\hline 38 & $11-\mathrm{BA}-32$ & 38.33637 & -118.97804 & Rhyolite of Bodie Creek & 1 \\
\hline 39 & 08SB032 & 38.34561 & -118.95580 & Unwelded tuff, Fletcher Basin & 1 \\
\hline 40 & $5-152-9 / 50 / 72$ & 38.3548 & -118.9261 & Hornblende trachydacite & 2 \\
\hline 41 & $5-152-9 / 56 / 72$ & 38.3548 & -118.9261 & Hornblende trachydacite & 2 \\
\hline 42 & $12-\mathrm{BA}-3$ & 38.34974 & -118.84729 & Trachyandesite of Mud Spring Canyon & 3 \\
\hline 43 & 10-BA-69 & 38.30537 & -119.13652 & Trachyandesite of Masonic & 1 \\
\hline 44 & 098-13D & 38.27655 & -119.16062 & Trachyandesite of Clark Canyon & 1 \\
\hline 45 & 09-BA-43 & 38.26358 & -119.16825 & Trachyandesite of Clark Canyon & 1 \\
\hline 46 & 203195 & 38.2823 & -119.1479 & Basaltic andesite of Locomotive Point & 3 \\
\hline 47 & $09-B A-47$ & 38.28409 & -119.13821 & Rhyolite of Bodie Hills & 1 \\
\hline 48 & 09-BA-42 & 38.27001 & -119.14887 & Rhyolite of Big Alkali & 1 \\
\hline
\end{tabular}


Table 1.-Continued

\begin{tabular}{|c|c|c|c|c|c|}
\hline $\begin{array}{c}\text { Map } \\
\text { location } \\
\text { number }\end{array}$ & Sample number & Latitude & Longitude & Unit; alteration zone; or mining district & $\begin{array}{c}\text { Appendix } \\
\text { number }\end{array}$ \\
\hline 49 & $088-21 \mathrm{~A}$ & 38.27363 & -119.13962 & Trachyandesite of Aurora Canyon & 1 \\
\hline 50 & 098-13B & 38.26802 & -119.13218 & Rhyolite of Bodie Hills & 1 \\
\hline 51 & MC-12-20 & 38.2701 & -119.1261 & Hornblende trachyandesite plug & 3 \\
\hline 52 & $088-23 F$ & 38.31068 & -119.11700 & Trachyandesite of Masonic & 1 \\
\hline 53 & 088-23D & 38.28113 & -119.10206 & Trachyandesite of Aurora Canyon & 1 \\
\hline 54 & $088-23 \mathrm{~A}$ & 38.27852 & -119.10021 & Trachyandesite of Aurora Canyon & 1 \\
\hline 55 & 088-23B & 38.27831 & -119.09908 & Trachyandesite of Aurora Canyon & 1 \\
\hline 56 & 08-BA-62 & 38.32006 & -119.04943 & Trachyandesite of Masonic & 1 \\
\hline 57 & $088-25 \mathrm{~A}$ & 38.27322 & -119.09077 & Trachyandesite of Aurora Canyon & 1 \\
\hline 58 & 09-BA-1 & 38.31968 & -119.04411 & Trachyandesite of Cow Camp Creek & 3 \\
\hline 59 & $077-8 \mathrm{C}$ & 38.27145 & -119.07783 & Trachyandesite of Aurora Canyon & 1 \\
\hline 60 & 077-8B & 38.28334 & -119.05617 & Trachydacite intrusion & 1 \\
\hline 61 & 088-21B & 38.26418 & -119.07504 & Trachydacite of Potato Peak & 1 \\
\hline 62 & 09-BA-35 & 38.29048 & -119.04642 & Trachydacite intrusion & 1 \\
\hline 63 & 09-BA-49 & 38.26389 & -119.04748 & Eureka Valley Tuff & 1 \\
\hline 64 & $11-\mathrm{BA}-60$ & 38.32693 & -118.97204 & Rhyolite of Bodie Creek & 1 \\
\hline 65 & 08-BA-65 & 38.31071 & -118.97808 & Rhyolite of Bald Peak & 1 \\
\hline 66 & $10-B A-67$ & 38.26200 & -118.98300 & Rhyolite of Bald Peak & 1 \\
\hline 67 & AU-10/61/DD61 & 38.26 & -118.981 & Eureka Valley Tuff & 2 \\
\hline 68 & $108-11 \mathrm{~A}$ & 38.27826 & -118.94807 & Rhyolite of Bodie Creek & 1 \\
\hline 69 & 077-9B & 38.26971 & -118.95063 & Rhyolite of Bodie Creek & 1 \\
\hline 70 & 077-9D & 38.28562 & -118.92803 & Rhyolite of Del Monte Canyon & 1 \\
\hline 71 & AU-6/60/DD61 & 38.285 & -118.928 & Rhyolite of Del Monte Canyon & 2 \\
\hline 72 & 077-9C & 38.27661 & -118.93036 & Rhyolite of Del Monte Canyon & 1 \\
\hline 73 & SAW11-9 & 38.29036 & -118.91657 & Alteration: Sawtooth Ridge alteration zone & 1 \\
\hline 74 & 077-9E & 38.31905 & -118.91003 & Trachyandesite of Del Monte & 1 \\
\hline 75 & $10-\mathrm{BA}-20$ & 38.31679 & -118.91129 & Rhyolite of Aurora Creek & 1 \\
\hline 76 & $10-\mathrm{BA}-21$ & 38.30315 & -118.89740 & Rhyolite of Aurora Creek & 1 \\
\hline 77 & $108-10 \mathrm{C}$ & 38.28052 & -118.90623 & Trachyandesite of West Brawley Peak & 1 \\
\hline 78 & $108-10 \mathrm{~A}$ & 38.27293 & -118.91272 & Trachyandesite of Aurora & 1 \\
\hline 79 & FA1 & 38.2931 & -118.8914 & Alteration: Aurora mining district, adularia in Prospectus vein & 2 \\
\hline 80 & $10-\mathrm{BA}-27$ & 38.27500 & -118.90498 & Rhyolite of East Brawley Peak & 1 \\
\hline 81 & AU-2/59/DD61 & 38.282 & -118.896 & Aurora mining district, adularia in Del Monte shaft dump & 2 \\
\hline 82 & AU-1/58/DD61 & 38.266 & -118.9 & Alteration: Aurora mining district, adularia in Esmeralda vein dump & 2 \\
\hline 83 & $00-B A-16$ & 38.2708 & -118.8908 & Trachyandesite of Aurora & 2 \\
\hline 84 & MC-12-19 & 38.31952 & -118.78154 & Trachyandesite of Borealis & 3 \\
\hline 85 & $39509-10$ & 38.21532 & -119.22755 & Dacite of Hot Springs Canyon & 1 \\
\hline 86 & $39509-3 \mathrm{~K}$ & 38.20793 & -119.22751 & Alteration: Cinnabar Canyon-US 395 alteration zone & 1 \\
\hline 87 & 088-24B & 38.25504 & -119.14115 & Trachyandesite of Willow Springs & 1 \\
\hline 88 & $088-24 \mathrm{~A}$ & 38.25278 & -119.13951 & Rhyolite of Big Alkali & 1 \\
\hline 89 & PP09-10A1 & 38.25309 & -119.13844 & Alteration: Aurora Canyon alteration zone & 1 \\
\hline 90 & $098-13 \mathrm{~A}$ & 38.25754 & -119.12788 & Rhyolite of Big Alkali & 1 \\
\hline 91 & CC09-9D1 & 38.19869 & -119.17050 & Alteration: Cinnabar Canyon-US 395 alteration zone & 1 \\
\hline 92 & CC09-9D2 & 38.19869 & -119.17050 & Alteration: Cinnabar Canyon-US 395 alteration zone & 1 \\
\hline 93 & $088-24 \mathrm{C}$ & 38.24786 & -119.11208 & Trachydacite of Potato Peak & 1 \\
\hline 94 & 12-BA-1 & 38.18995 & -119.16513 & Trachydacite of Cinnabar Canyon & 1 \\
\hline 95 & 077-7C & 38.19677 & -119.15829 & Rhyolite of Del Monte Canyon & 1 \\
\hline 96 & $08-B A-46$ & 38.24430 & -119.10385 & Alteration: Potato Peak alteration zone, Alta Pina mine & 1 \\
\hline
\end{tabular}


Table 1.-Continued

\begin{tabular}{|c|c|c|c|c|c|}
\hline $\begin{array}{c}\text { Map } \\
\text { location } \\
\text { number }\end{array}$ & Sample number & Latitude & Longitude & Unit; alteration zone; or mining district & $\begin{array}{c}\text { Appendix } \\
\text { number }\end{array}$ \\
\hline 97 & $08-\mathrm{BA}-50$ & 38.24816 & -119.09663 & Rhyolite of Bodie Hills & 1 \\
\hline 98 & $077-7 \mathrm{~B}$ & 38.19178 & -119.15240 & Trachyandesite of Willow Springs & 1 \\
\hline 99 & $098-13 \mathrm{C}$ & 38.25072 & -119.09223 & Trachydacite of Potato Peak & 1 \\
\hline 100 & 098-10C & 38.24919 & -119.09203 & Trachydacite of Potato Peak & 1 \\
\hline 101 & 088-21D & 38.24330 & -119.09209 & Trachydacite of Potato Peak & 1 \\
\hline 102 & 098-10B & 38.25135 & -119.08382 & Rhyolite of Bodie Hills & 1 \\
\hline 103 & $088-21 \mathrm{C}$ & 38.25134 & -119.08382 & Rhyolite of Bodie Hills & 1 \\
\hline 104 & 088-24D & 38.22678 & -119.10376 & Trachydacite of Potato Peak & 1 \\
\hline 105 & $088-21 \mathrm{E}$ & 38.23457 & -119.08582 & Trachydacite of Potato Peak & 1 \\
\hline 106 & 088-24E & 38.21809 & -119.10188 & Trachydacite of Potato Peak & 1 \\
\hline 107 & 08-BA-61 & 38.20769 & -119.10175 & Trachydacite of Potato Peak & 1 \\
\hline 108 & $088-24 \mathrm{~F}$ & 38.20176 & -119.08978 & Trachyandesite of Willow Springs & 1 \\
\hline 109 & $108-12 \mathrm{~A}$ & 38.24252 & -119.04825 & Trachydacite of Potato Peak & 1 \\
\hline 110 & 08-BA-68 & 38.19323 & -119.06835 & Trachydacite of Potato Peak & 1 \\
\hline 111 & 108-12B & 38.23830 & -119.00784 & Trachydacite of Potato Peak & 1 \\
\hline 112 & 08-BA-66 & 38.18629 & -119.05680 & Dacite of Silver Hill, debris flow clast & 1 \\
\hline 113 & $12-\mathrm{BA}-17$ & 38.21961 & -119.00019 & Alteration: Bodie mining district, vein adularia, west of Bodie Bluff & 1 \\
\hline 114 & $077-7 \mathrm{~F}$ & 38.20252 & -119.02630 & Dacite of Silver Hill & 1 \\
\hline 115 & BOD11-3A & 38.21961 & -119.00354 & Alteration: Bodie mining district, vein adularia, Upper Hobart Tunnel dump & 1 \\
\hline 116 & BOD11-3B & 38.21961 & -119.00354 & Alteration: Bodie mining district, vein adularia, Bodie Bluff & 1 \\
\hline 117 & 077-6C & 38.21870 & -119.00050 & Alteration: Bodie mining district, vein adularia, Bodie Bluff & 1 \\
\hline 118 & AU-16/63/DD61 & 38.215 & -119.004 & Alteration: Bodie mining district, vein adularia, south of Bodie Bluff & 2 \\
\hline 119 & $077-6 \mathrm{~A}$ & 38.21490 & -119.00370 & Alteration: Bodie mining district, vein adularia, south of Bodie Bluff & 1 \\
\hline 120 & 11-BA-22 & 38.21257 & -119.00402 & Alteration: Bodie mining district, vein adularia, south of Bodie Bluff & 1 \\
\hline 121 & BOD11-4E & 38.21257 & -119.00402 & Alteration: Bodie mining district, vein adularia, Standard Hill Mine & 1 \\
\hline 122 & 11-BA-21 & 38.20370 & -119.00919 & Alteration: Bodie mining district, vein adularia, Red Cloud mine & 1 \\
\hline 123 & AU-17/64/DD61 & 38.215 & -118.997 & Alteration: Bodie mining district, vein adularia, south of Bodie Bluff & 2 \\
\hline 124 & BOD09-5 & 38.20424 & -119.00755 & Alteration: Bodie mining district, vein adularia, Oro mine dump & 1 \\
\hline 125 & 11-BA-7G & 38.20420 & -119.00649 & Alteration: Bodie mining district, vein adularia, Silver Hill & 1 \\
\hline 126 & BOD09-3 & 38.20138 & -119.00575 & Alteration: Bodie mining district, vein adularia, Red Cloud Mine & 1 \\
\hline 127 & 09-BA-28I & 38.20151 & -119.00360 & Alteration or mineralization: Bodie, Red Cloud mine & 1 \\
\hline 128 & AU-18/65/DD61 & 38.201 & -119.004 & Alteration or mineralization: Bodie, Red Cloud mine & 2 \\
\hline 129 & 09-BA-26 & 38.20360 & -119.00021 & Dacite of Silver Hill & 1 \\
\hline 130 & $077-7 \mathrm{G}$ & 38.23439 & -118.96671 & Trachyandesite of West Brawley Peak & 1 \\
\hline 131 & $077-6 \mathrm{~F}$ & 38.18809 & -119.00854 & Dacite of Silver Hill-Sugarloaf plug & 1 \\
\hline 132 & 077-9A & 38.22088 & -118.97443 & Eureka Valley Tuff & 1 \\
\hline 133 & $108-12 \mathrm{C}$ & 38.18925 & -118.98343 & Dacite of Silver Hill & 1 \\
\hline 134 & $108-12 \mathrm{E}$ & 38.20763 & -118.96489 & Dacite of Silver Hill & 1 \\
\hline 135 & FA66 & 38.2375 & -118.9008 & Alteration: East Brawley Peak alteration zone, vein alunite & 2 \\
\hline 136 & $00-B A-26$ & 38.2542 & -118.8841 & Trachyandesite of Aurora & 2 \\
\hline 137 & AUR10-3 & 38.23752 & -118.89919 & Alteration: East Brawley Peak alteration zone, vein alunite & 1 \\
\hline 138 & 077-7A & 38.17860 & -119.19476 & Trachyandesite of Willow Springs & 1 \\
\hline 139 & 08-BA-51 & 38.17449 & -119.15441 & Trachyandesite of Willow Springs & 1 \\
\hline 140 & 09-BA-22 & 38.14302 & -119.17974 & Trachyandesite of Mt. Biedeman & 1 \\
\hline 141 & $09-B A-23$ & 38.12851 & -119.17491 & Tuff of Jacks Spring & 1 \\
\hline 142 & 098-11B & 38.12451 & -119.17126 & Trachydacite of Bridgeport Canyon & 1 \\
\hline 143 & 098-11A & 38.12239 & -119.16954 & Tuff of Jacks Spring & 1 \\
\hline
\end{tabular}


Table 1.-Continued

\begin{tabular}{|c|c|c|c|c|c|}
\hline $\begin{array}{c}\text { Map } \\
\text { location } \\
\text { number }\end{array}$ & Sample number & Latitude & Longitude & Unit; alteration zone; or mining district & $\begin{array}{l}\text { Appendix } \\
\text { number }\end{array}$ \\
\hline 144 & $10-\mathrm{BA}-46$ & 38.17380 & -119.11508 & Trachyandesite of Mount Biedeman & 1 \\
\hline 145 & $10-B A-66$ & 38.17250 & -119.10125 & Trachydacite of Potato Peak & 1 \\
\hline 146 & 09SB015A & 38.12310 & -119.14843 & Trachyandesite of Mount Biedeman & 1 \\
\hline 147 & 098-11E & 38.11099 & -119.15841 & Trachyandesite of Mount Biedeman & 1 \\
\hline 148 & 077-7D & 38.16719 & -119.09983 & Rhyolite of Bodie Hills & 1 \\
\hline 149 & 09SB020A & 38.13230 & -119.13277 & Trachydacite of Bridgeport Canyon & 1 \\
\hline 150 & $108-9 \mathrm{~A}$ & 38.16540 & -119.09816 & Trachyandesite of Mount Biedeman & 1 \\
\hline 151 & $108-12 \mathrm{~F}$ & 38.16336 & -119.09918 & Trachyandesite of Mount Biedeman & 1 \\
\hline 152 & MC-12-18 & 38.15575 & -119.07825 & Trachyandesite of Mount Biedeman & 3 \\
\hline 153 & $12-B A-22$ & 38.10151 & -119.12400 & Trachyandesite of Mount Biedeman & 1 \\
\hline 154 & $6-181-12 / 52 / \mathrm{DD} 72$ & 38.1193 & -119.1039 & Tuff of Jacks Spring & 2 \\
\hline 155 & 6-181-12/53/DD72 & 38.1193 & -119.1039 & Tuff of Jacks Spring & 2 \\
\hline 156 & $6-215-1 / 121 / 72$ & 38.1344 & -119.0825 & Trachyandesite of Mount Biedeman & 2 \\
\hline 157 & 119-20B & 38.13452 & -119.07613 & Trachyandesite of Mount Biedeman, plug & 1 \\
\hline 158 & 09-BA-20 & 38.15662 & -119.04741 & Rhyolite of Bodie Hills & 1 \\
\hline 159 & $10-B A-61$ & 38.14005 & -119.01551 & Trachyandesite of Mount Biedeman & 1 \\
\hline 160 & $108-12 \mathrm{D}$ & 38.17315 & -118.97800 & Dacite of Silver Hill & 1 \\
\hline
\end{tabular}

Table 2. Map location numbers for K-Ar geochronology samples from the Bodie Hills volcanic field, California and Nevada.

\begin{tabular}{|c|c|c|c|c|}
\hline $\begin{array}{c}\text { Map location } \\
\text { letter }\end{array}$ & Sample number & Latitude & Longitude & Unit \\
\hline A & 1071 & 38.175 & -118.832 & Pyroxene trachyandesite of Cedar Hill \\
\hline B & 469 & 38.179 & -118.826 & Pyroxene trachyandesite of Cedar Hill \\
\hline $\mathrm{C}$ & 468 & 38.178 & -118.819 & Hornblende trachydacite of Cedar Hill \\
\hline $\mathrm{D}$ & 466 & 38.179 & -118.821 & Pyroxene trachyandesite of Cedar Hill \\
\hline $\mathrm{E}$ & 465 & 38.181 & -118.823 & Pyroxene trachyandesite of Cedar Hill \\
\hline $\mathrm{F}$ & 1069 & 38.188 & -118.850 & Hornblende trachydacite of Cedar Hill \\
\hline G & 139 & 38.209 & -118.880 & Hornblende trachydacite of Cedar Hill \\
\hline $\mathrm{H}$ & 199 & 38.153 & -119.008 & Hornblende trachydacite of Cedar Hill \\
\hline I & 144 & 38.184 & -118.894 & Trachyandesite of Cedar Hill \\
\hline $\mathrm{J}$ & $1092 \mathrm{~A}$ & 38.255 & -118.810 & Rhyolite of Spring Peak \\
\hline K & 25 & 38.261 & -118.973 & Basaltic trachyandesite of Beauty Peak \\
\hline $\mathrm{L}$ & 120 & 38.240 & -118.829 & Trachyandesite of Mount Hicks \\
\hline M & 15 & 38.194 & -118.961 & Dacite of Silver Hill \\
\hline $\mathrm{N}$ & 414 & 38.177 & -119.193 & Trachyandesite of Willow Springs \\
\hline $\mathrm{O}$ & 406 & 38.234 & -119.085 & Trachydacite of Potato Peak \\
\hline$P$ & 507 & 38.154 & -119.089 & Rhyolite of Bodie Hills \\
\hline Q & 459 & 38.097 & -119.064 & Eureka Valley Tuff \\
\hline $\mathrm{R}$ & 31 & 38.247 & -118.990 & Eureka Valley Tuff \\
\hline S & 27 & 38.247 & -118.990 & Eureka Valley Tuff \\
\hline $\mathrm{T}$ & W24 & 38.102 & -119.066 & Eureka Valley Tuff \\
\hline $\mathrm{U}$ & W25 & 38.131 & -119.181 & Eureka Valley Tuff \\
\hline V & 547 & 38.255 & -118.948 & Trachyandesite of West Brawley Peak \\
\hline W & USGS(M)-711-67 & 38.2894 & -118.9092 & Trachyandesite of Aurora \\
\hline
\end{tabular}


Table 2.-Continued

\begin{tabular}{|c|c|c|c|c|}
\hline $\begin{array}{l}\text { Map location } \\
\text { letter }\end{array}$ & Sample number & Latitude & Longitude & Unit \\
\hline $\mathrm{X}$ & USGS(M)-668-G10 & 38.2403 & -118.8917 & Trachyandesite of Aurora \\
\hline Y & USGS(M)-711-8 & 38.2681 & -118.8917 & Trachyandesite of Aurora \\
\hline $\mathrm{Z}$ & USGS(M)-712-1 & 38.2522 & -118.9175 & Trachyandesite of West Brawley Peak \\
\hline AA & USGS(M)-710-7 & 38.2822 & -118.9281 & Rhyolite of Del Monte Canyon \\
\hline BB & USGS(M)-NTS10B & 38.3021 & -118.8967 & Rhyolite of Aurora Creek \\
\hline $\mathrm{CC}$ & USGS(M)-Baghdad & 38.2786 & -118.9467 & Rhyolite of Bodie Creek \\
\hline DD & USGS(M)-670G4 & 38.2811 & -118.8842 & Rhyolite of Martinez Hill \\
\hline $\mathrm{EE}$ & USGS(M)-610-1B & 38.2778 & -118.8586 & Rhyodacite of Aurora Peak \\
\hline FF & USGS(M)-672-2 & 38.3128 & -118.8825 & Trachyandesite of Aurora Crater \\
\hline GG & USGS(M)-611-5 & 38.2578 & -118.8558 & Trachyandesite south of Aurora Peak \\
\hline $\mathrm{HH}$ & BH31 & 38.194 & -119.008 & Dacite of Silver Hill, plug \\
\hline II & 5 & 38.0978 & -119.1475 & Trachyandesite of Sinnamon Cut \\
\hline JJ & 6 & 38.1256 & -119.1697 & Basaltic trachyandesite of Rancheria \\
\hline KK & 37 & 38.287 & -118.887 & Alteration or mineralization: Trachyandesite of Aurora \\
\hline LL & CH8Z1 & 38.288 & -118.882 & Trachyandesite of Aurora \\
\hline MM & USGS(M)-7346-1 & 38.215 & -119.004 & Alteration or mineralization: Bodie \\
\hline $\mathrm{NN}$ & USGS(M)-RCD1B & 38.201 & -119.005 & Alteration or mineralization: Bodie \\
\hline $\mathrm{OO}$ & USGS(M)-B270 & 38.216 & -119.004 & Alteration or mineralization: Bodie \\
\hline PP & USGS(M)-BH15 & 38.201 & -119.003 & Dacite of Silver Hill \\
\hline QQ & USGS(M)-S1 & 38.188 & -119.008 & Dacite of Silver Hill \\
\hline $\mathrm{RR}$ & USGS(M)-B271 & 38.215 & -119.003 & Dacite of Silver Hill \\
\hline SS & USGS(M)-856-8 & 38.214 & -119.004 & Dacite of Silver Hill \\
\hline TT & USGS(M)-BH17 & 38.193 & -119.012 & Dacite of Silver Hill \\
\hline UU & USGS(M)-7346-3 & 38.216 & -118.981 & Hornblende trachydacite of Cedar Hill \\
\hline VV & USGS(M)-BH32 & 38.200 & -118.995 & Dacite of Silver Hill \\
\hline WW & USGS(M)-856-32 & 38.209 & -118.997 & Dacite of Silver Hill \\
\hline $\mathrm{XX}$ & USGS(M)-856-10 & 38.205 & -119.028 & Trachydacite of Potato Peak \\
\hline YY & USGS(M)-BH26 & 38.194 & -119.003 & Dacite of Silver Hill \\
\hline $\mathrm{ZZ}$ & USGS(M)-BH16 & 38.200 & -118.999 & Dacite of Silver Hill \\
\hline AAA & USGS(M)-854-1 & 38.182 & -119.003 & Dacite of Silver Hill \\
\hline BBB & USGS(M)-BH29 & 38.196 & -118.958 & Dacite of Silver Hill \\
\hline $\mathrm{CCC}$ & USGS(M)-BM2 & 38.221 & -119.057 & Trachydacite of Potato Peak \\
\hline DDD & USGS(M)-BH9 & 38.157 & -119.116 & Trachyandesite of Mount Biedeman \\
\hline EEE & USGS(M)-MTB1 & 38.146 & -119.073 & Trachyandesite of Mount Biedeman \\
\hline FFF & USGS(M)-BH27 & 38.140 & -119.056 & Rhyolite of Bodie Hills \\
\hline GGG & USGS(M)-BH19A & 38.222 & -119.172 & Trachyandesite of Willow Springs \\
\hline HHH & USGS(M)-BH6 & 38.1655 & -119.1512 & Rhyolite of Big Alkali \\
\hline III & USGS(M)-BH20 & 38.220 & -119.149 & Rhyolite of Big Alkali \\
\hline JJJ & 23 & 38.156 & -118.860 & Trachybasalt of Cedar Hill \\
\hline KKK & 158 & 38.368 & -118.812 & Trachyandesite of Mud Spring \\
\hline LLL & 160 & 38.357 & -118.896 & Trachyandesite of Aurora Crater \\
\hline MMM & KA2362 & 38.4408 & -118.9725 & Hornblende andesite \\
\hline NNN & KA2364 & 38.4408 & -118.9725 & Hornblende andesite \\
\hline $\mathrm{OOO}$ & KA2368 & 38.4408 & -118.9725 & Hornblende andesite \\
\hline PPP & KA2379R & 38.4133 & -118.9417 & Aldrich Station Formation, tuff \\
\hline QQQ & $742-45$ & 38.0869 & -119.1431 & Basaltic trachyandesite of Rancheria \\
\hline RRR & EL-KA-2 & 38.3047 & -118.7799 & Andesite \\
\hline
\end{tabular}




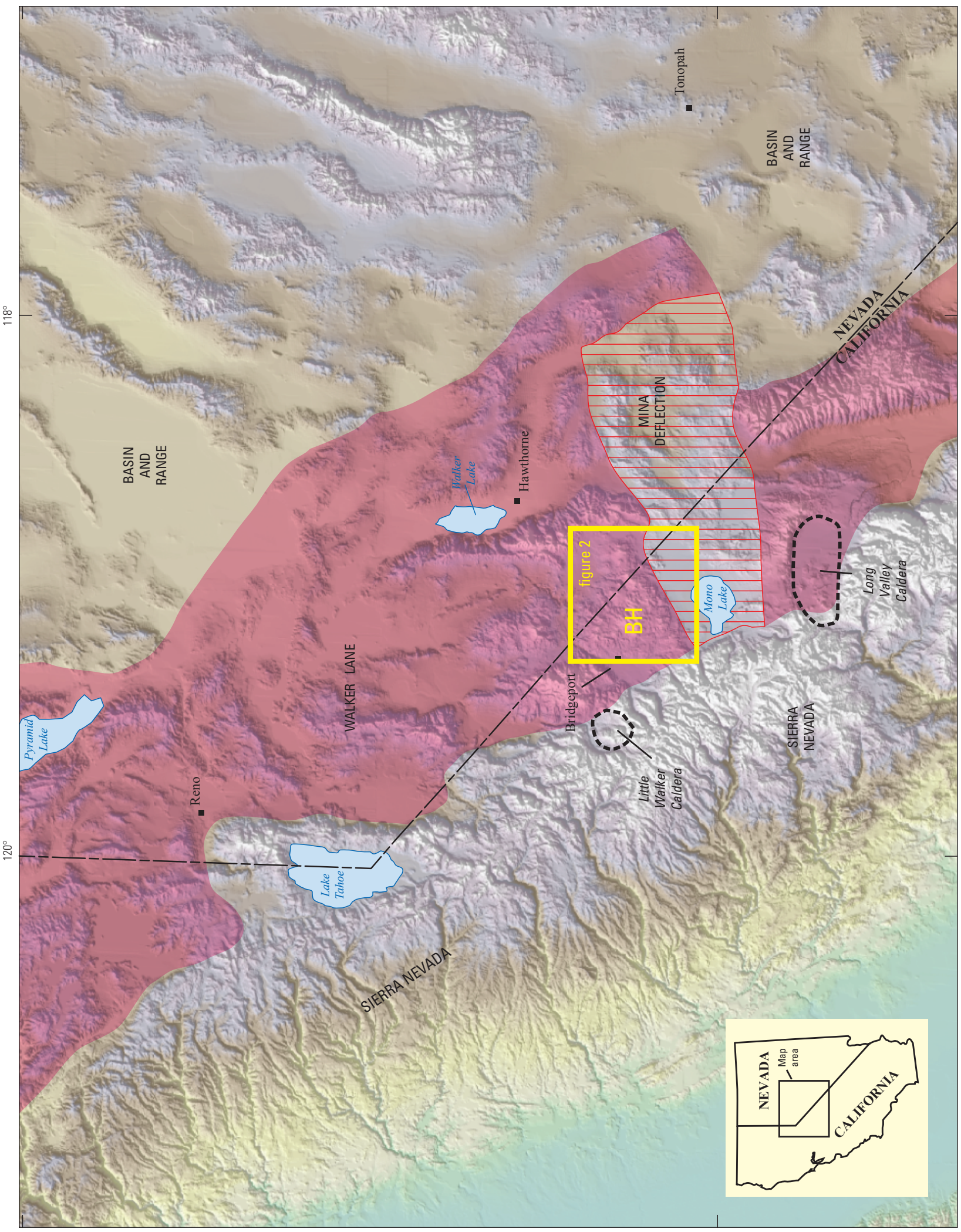

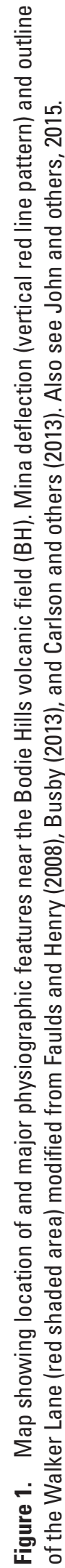




\section{${ }^{40} \mathrm{Ar} /{ }^{39} \mathrm{Ar}$ Analytical Methods}

New ${ }^{40} \mathrm{Ar} /{ }^{39} \mathrm{Ar}$ age determinations provide temporal constraints on volcanic and hydrothermal activity in the Bodie Hills (figs. 2 and 3). Volcanic rocks were dated using either separates of one or more phenocryst mineral (plagioclase, sanidine, biotite, hornblende) or whole-rock aggregates. Ages of hydrothermal alteration were determined using separates of alunite, K-feldspar, or adularia. Where practical, multiple minerals from individual samples were dated to provide abundant confirmation of the results, but also to evaluate and document argon systematics of the different mineral phases nucleated under various magmatic and hydrothermal conditions.

Samples collected for ${ }^{40} \mathrm{Ar} /{ }^{39} \mathrm{Ar}$ analysis were crushed and sieved to sizes appropriate for preparation of high-purity separates. Standard magnetic and heavy-liquid separation techniques were used to make mineral separations. Wholerock samples were prepared by crushing and isolating $\sim 1 \mathrm{~mm}^{3}$ rock fragments from fresh rock that was free of obvious alteration and xenocrysts. Analyzed samples were washed in deionized water. In many cases, final separates were prepared by hand picking individual crystals.

Samples whose ages were determined at the U.S. Geological Survey ${ }^{40} \mathrm{Ar} /{ }^{39} \mathrm{Ar}$ lab in Menlo Park, CA (Appendix 1) were irradiated in the U.S. Geological Survey TRIGA Reactor Facility in Denver, Colorado; irradiation times were between 10 and 16 hours, although biotite, plagioclase, and sanidine from the rhyolite of Bodie Hills (map location number 102) were also analyzed in both 2-hour and 24-hour irradiations. Plagioclase, biotite, hornblende, and alunite ages were obtained using incremental-heating analysis, that is, incremental extraction of argon at progressively higher temperatures until all gas is released. Incremental heating analyses utilized a low-blank, tantalum and molybdenum, resistance-heated furnace. During heating, all argon gas was released in 8-15 temperature-controlled increments or steps; a few hornblende and potassium feldspar experiments required as many as 18 steps. Ages from incremental-heating experiments were determined by evaluating ${ }^{40} \mathrm{Ar} /{ }^{39} \mathrm{Ar}$ age spectra and isochron diagrams. Data for many of the individual sample ages constitute ${ }^{40} \mathrm{Ar} /{ }^{39} \mathrm{Ar}$ plateaus, defined as the weighted mean age of contiguous gas fractions representing $>50 \%$ of the ${ }^{39} \mathrm{Ar}$ released for which no difference can be detected between the ages of any two fractions at the $95 \%$ level of confidence (Fleck and others, 1977). Where no plateau was defined, either the ${ }^{40} \mathrm{Ar} /{ }^{39} \mathrm{Ar}$ isochron age or the integrated age of all increments was defined as the age of the sample.

Most sanidine and biotite ages determined at the U.S. Geological Survey ${ }^{40} \mathrm{Ar}{ }^{{ }^{9}} \mathrm{Ar}$ lab in Menlo Park, CA were obtained by laser-fusion analysis, whereby grains were fused with a $\mathrm{CO}_{2}$ laser in a single heating step (Appendix 1). One or several grains were used in each analysis, depending on grain size. In all cases, a minimum number of grains were used to permit recognition and elimination of most xenocrystic or detrital contamination through identification of outliers. The reported age for laser-fusion analyses represents the weighted mean of the replicate analyses, with the inverse variance of propagated, within-run (internal) errors of each used as its weighting factor (Taylor, 1982). Sanidine from the Taylor Creek Rhyolite (TCR-2) was used for calculation of neutron flux in all irradiations up to IRR290 (Appendix 1). Subsequent irradiations (higher IRR numbers in Appendix 1) used Bodie Hills sanidine (098-10B), calibrated to TCR-2, as the flux monitor. Regardless of the monitor mineral used, all ages in Appendix 1 are reported relative to an age of 28.02 Ma for the Fish Canyon Tuff sanidine standard (Renne and others, 1998) with uncertainties estimated at the one-sigma level, unless stated. Decay and abundance constants are those recommended by Steiger and Jäger (1977). Ages were calculated assuming a ${ }^{40} \mathrm{Ar} /{ }^{36} \mathrm{Ar}$ ratio of trapped argon equal to the atmospheric value of 295.5 .

The ${ }^{40} \mathrm{Ar} r{ }^{39} \mathrm{Ar}$ ages reported in Appendix 2, determined in the U.S. Geological Survey ${ }^{40} \mathrm{Ar}{ }^{39} \mathrm{Ar}$ lab in Denver, Colorado by L.W. Snee, are based on analyses of biotite, hornblende, plagioclase, or sanidine phenocrysts; hydrothermal K-feldspar, adularia, or alunite; and one whole rock analysis (Appendix 2). Analyzed materials were packaged in aluminum foil and stacked in quartz glass vials with monitor minerals placed between every second sample and at the top and bottom of each vial. Samples were irradiated in the U.S. Geological Survey's TRIGA reactor in Denver, Colorado, in irradiation packages DD61, DD72, and DD78. Irradiated samples were heated in temperature steps in a double-vacuum furnace, and the released gasses were cleaned according to procedures described by Snee (2002). Argon isotopic total abundances $\left({ }^{40} \mathrm{Ar}_{\mathrm{T}},{ }^{39} \mathrm{Ar}_{\mathrm{T}},{ }^{38} \mathrm{Ar}_{\mathrm{T}},{ }^{37} \mathrm{Ar}_{\mathrm{T}}\right.$, and $\left.{ }^{36} \mathrm{Ar}_{\mathrm{T}}\right)$ were measured on a MAP 215 mass spectrometer on a Faraday collector in volts to five decimal places. Corrected abundances for ${ }^{40} \mathrm{Ar}_{\mathrm{R}}$ (radiogenic ${ }^{40} \mathrm{Ar}$ ), ${ }^{40} \mathrm{Ar}_{\mathrm{K}}$ (irradiation-produced $\mathrm{K}$-derived ${ }^{40} \mathrm{Ar}$ ), ${ }^{40} \mathrm{Ar}_{\mathrm{I}}$ (initial ${ }^{40} \mathrm{Ar}$ ), ${ }^{39} \mathrm{Ar}_{\mathrm{K}}$ (irradiation-produced K-derived ${ }^{39} \mathrm{Ar}$ ), ${ }^{38} \mathrm{Ar}_{\mathrm{Cl}}$ (irradiation-produced Cl-derived ${ }^{38} \mathrm{Ar}$ ), ${ }^{37} \mathrm{Ar}$ Ca (irradiation produced Ca-derived ${ }^{37} \mathrm{Ar}$, and ${ }^{36} \mathrm{Ar}_{\mathrm{I}}$ (initial ${ }^{36} \mathrm{Ar}$ ) are in volts. All estimated uncertainties in measured voltages are reported in Appendix 2 at one sigma. Voltages may be converted to moles using $1.160 \times 10^{-12}$ moles argon per volt signal. The " $\mathrm{F}$ " value $\left({ }^{40} \mathrm{Ar}_{\mathrm{R}}{ }^{\beta 9} \mathrm{Ar}_{\mathrm{K}}\right)$ for each temperature step was directly calculated from ${ }^{40} \mathrm{Ar}_{\mathrm{R}}$ divided by ${ }^{39} \mathrm{Ar}_{\mathrm{K}}$. $\mathrm{K} / \mathrm{Ca}$ was calculated from the expression $\mathrm{K} / \mathrm{Ca}=0.5\left({ }^{39} \mathrm{Ar}_{\mathrm{K}} /{ }^{37} \mathrm{Ar} \mathrm{Ca}_{\mathrm{a}}\right)$. All isotopic abundances in Appendix 2 have been corrected for mass discrimination. Mass discrimination was determined by calculating the ${ }^{40} \mathrm{Ar} /{ }^{36} \mathrm{Ar}$ ratio of aliquots of atmospheric argon pipetted from a fixed pipette on the extraction line; the ratio during these experiments was 298.9, which was corrected to 295.5 to account for mass discrimination. Final isotopic abundances were corrected for all interfering isotopes of argon including atmospheric argon. ${ }^{37} \mathrm{Ar}$ and ${ }^{39} \mathrm{Ar}$, which are produced during irradiation, are radioactive and their 
abundances were corrected for radioactive decay. Abundances of interfering isotopes from $\mathrm{K}$ and $\mathrm{Ca}$ were calculated from reactor production ratios determined by irradiating and analyzing pure $\mathrm{CaF}_{2}$ and $\mathrm{K}_{2} \mathrm{SO}_{4}$; the $\mathrm{K}_{2} \mathrm{SO}_{4}$ was degassed in a vacuum furnace prior to irradiation to release extraneous argon. Corrections for $\mathrm{Cl}$-derived ${ }^{36} \mathrm{Ar}$ were determined using the method of Roddick (1983). Production ratios for these experiments are documented by Snee (2002). Apparent ages of each fraction include the error in $J$ value ( 0.1 percent), which was calculated from the reproducibility of splits of the argon from several standards. The standards for this experiment were hornblende MMhb-1, using an age of 523.1 $\pm 2.6 \mathrm{Ma}$ (Samson and Alexander, 1987; Renne and others, 1998), and sanidine FCT1, using an age of $27.84 \mathrm{Ma}$, as measured in the Denver Argon Laboratory against MMhb-1 (Snee, 2002). Apparent ages were calculated using decay constants of Steiger and Jäger (1977). All apparent age errors are cited at one sigma. Uncertainties associated with apparent ages of individual fractions were calculated using equations of Dalrymple and others (1981). Isochron diagrams were produced for all samples and may be derived by using ${ }^{40} \mathrm{Ar}_{\mathrm{I}}$ (initial ${ }^{40} \mathrm{Ar}$ ) and ${ }^{36} \mathrm{Ar}_{\mathrm{I}}$ (initial ${ }^{36} \mathrm{Ar}$ ). Plateaus were determined according to the method of Fleck and others (1977).

The ${ }^{40} \mathrm{Ar} /{ }^{39} \mathrm{Ar}$ ages reported in Appendix 3, determined in the U.S. Geological Survey ${ }^{40} \mathrm{Ar} /{ }^{39} \mathrm{Ar}$ lab in Denver, CO by M.A. Cosca, are based on analyses of amphibole (hornblende), plagioclase, and whole rock samples. Samples, together with standards, were irradiated for $20 \mathrm{MW}$ (megawatt) hours in the central thimble position of the USGS TRIGA reactor. Laser fusion of $>10$ individual Fish Canyon Tuff sanidine crystals (28.201 \pm 0.09 Ma; Kuiper and others, 2008) at each closely monitored position within the irradiation package resulted in neutron flux ratios reproducible to $\pm 0.25 \%$ (two sigma). Isotopic production ratios and interfering nucleogenic reactions were determined from irradiated $\mathrm{CaF}_{2}$ and $\mathrm{KCl}$ salts and zero age $\mathrm{K}$-silicate glass, and for this study the following values were measured: $\left({ }^{36} \mathrm{Ar} \times{ }^{37} \mathrm{Ar}\right)_{\mathrm{Ca}}=(2.77 \pm 0.03) \times 10^{-4}$; $\left({ }^{39} \mathrm{Ar}{ }^{\left({ }^{77}\right.} \mathrm{Ar}\right)_{\mathrm{Ca}}=(6.54 \pm 0.33) \times 10^{-4} ;$ and $\left({ }^{38} \mathrm{Ar} /{ }^{39} \mathrm{Ar}\right)_{\mathrm{K}}=(1.29 \pm$ $0.03) \times 10^{-2}$. Cadmium shielding during irradiation prevented any measurable nucleogenic $\left({ }^{40} \mathrm{Ar} /{ }^{39} \mathrm{Ar}\right)_{\mathrm{K}}$. The irradiated samples and standards were loaded into numbered positions of a stainless steel planchette, placed into a laser sample chamber with an externally pumped $\mathrm{ZnSe}$ window, and evacuated to ultrahigh vacuum conditions in a fully automated stainless steel extraction line designed and built at the USGS in Denver. The samples were incrementally heated using a $25 \mathrm{~W} \mathrm{CO}_{2}$ laser equipped with a beam homogenizing lens and the liberated gas was expanded and purified by exposure to a cryogenic trap maintained at $-140^{\circ} \mathrm{C}$ and two hot SAES GP50 getters. Following purification the gas was expanded online into a Thermo Scientific ARGUS VI mass spectrometer (except sample 203195, which was analyzed using a Mass Analyzer Products 215-50 mass spectrometer) in static mode and Ar isotopes were measured by peak jumping using an electron multiplier in analog mode. Data were acquired during 10 measurement cycles and time zero intercepts were determined by best-fit linear and (or) polynomial regressions to the data. Ages were calculated assuming a ${ }^{40} \mathrm{Ar} /{ }^{36} \mathrm{Ar}$ ratio of trapped argon equal to the atmospheric value of 298.56 (Lee and others, 2006) and using decay constants of Steiger and Jäger (1977). Data were corrected for mass discrimination, blanks, radioactive decay, and interfering nucleogenic reactions.

\section{K-Ar Analytical Methods}

Conventional K-Ar analyses were not carried out as part of the this study, but previous workers produced considerable $\mathrm{K}$-Ar age data that constitute an important source of stratigraphic information on the Bodie Hills volcanic field and on the timing of mineralization in the Bodie and Aurora mining districts. Many earlier K-Ar analyses were performed in K-Ar laboratories at USGS facilities in Menlo Park and Denver or at University of California laboratories in Berkeley. An appropriate reference for K-Ar techniques used in all three laboratories is found in Dalrymple and Lanphere (1969).

\section{Data}

All available geochronology data for Bodie Hills volcanic field are summarized in table 3 . These data are synthesized and interpreted in other publications, including John and others (2012, 2015), Vikre and others (2015) and du Bray and others (written commun., 2015). As described previously, ages reported in Appendixes 1-3 utilized several slightly different ages for the Fish Canyon Tuff sanidine standard as a consequence of these age determinations having been conducted in several different labs, over a period of almost fifteen years, during which the accepted age for the sanidine standard was refined. In order to render ages calculated using different values for the sanidine standard comparable, ages calculated using a sanidine standard age different from 28.02 Ma were recalculated using that value and are summarized in the column titled "Age recalculated for FCT $=28.02$ " (table 3 ).

\section{Acknowledgments}

Geologic mapping and sample collection for this study were conducted as part of the Mineral Systems of the Ancestral and Modern Cenozoic Cascades Arcs Project funded by the U.S. Geological Survey Mineral Resources Program. Technical assistance was provided in Menlo Park laboratories by Dean Miller, Donald Shamp, and James Saburomaru. In Denver, Ross Yeoman and John Lee offered similar assistance. Byron R. Berger (deceased) introduced L.W. Snee to the geology of the Bodie Hills and was instrumental in geochronology sample collection. Constructive reviews by R.D. Taylor and J.N. Aleinikoff are much appreciated and helped clarify data presentation. 

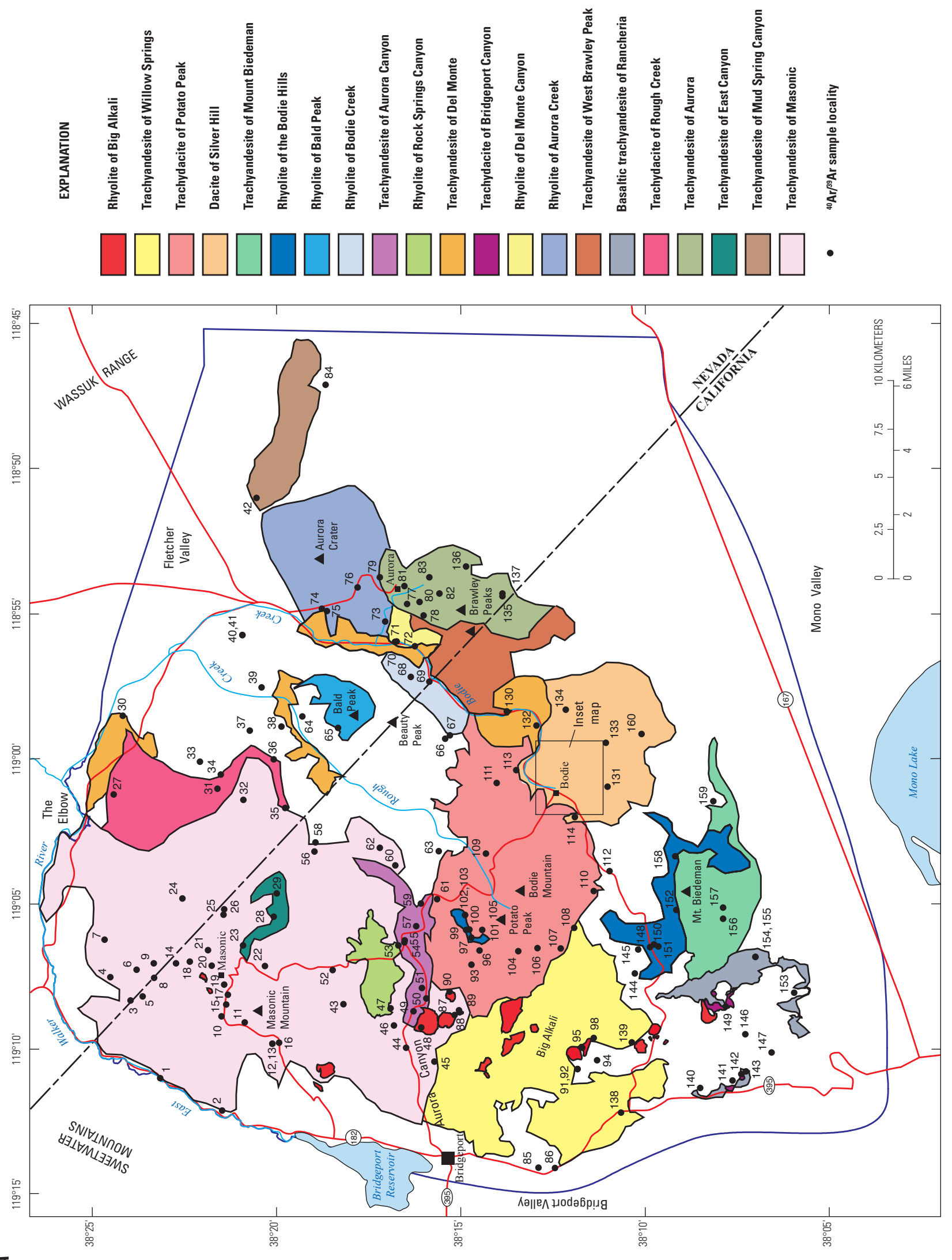

흥 월 을

.월

능 흥 뜨

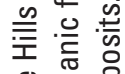

응 응 웜

制

导 章

渮

을 힝

늘 흥

든

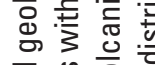

응

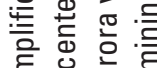

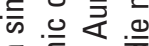

ฮ

ธ。

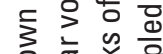

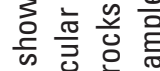

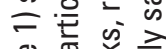

음 品

画衰遂

등 ฮ

贾

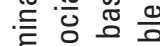

产

훵

迅응 윰

这을 일

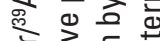

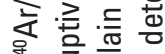

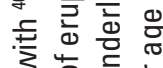

范立

क

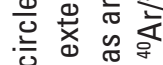

前 产㐘

元 흥혀

음 은흥 원

응 응

응 긍흐 음

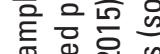

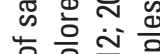

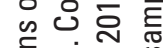

흘 क्ष் w

过 侸

立说 음

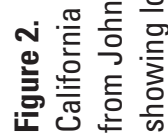




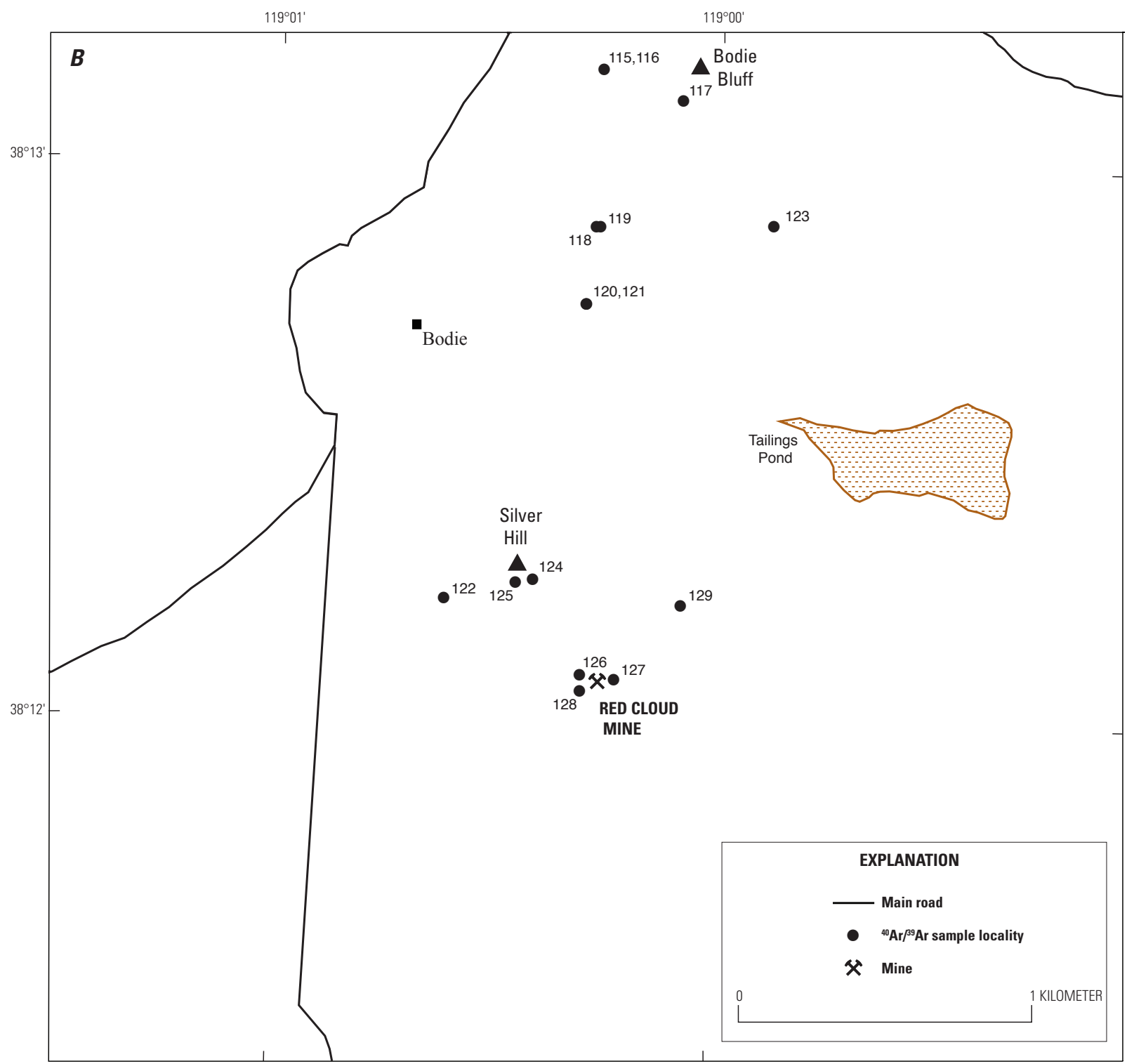

Figure 2.-Continued 

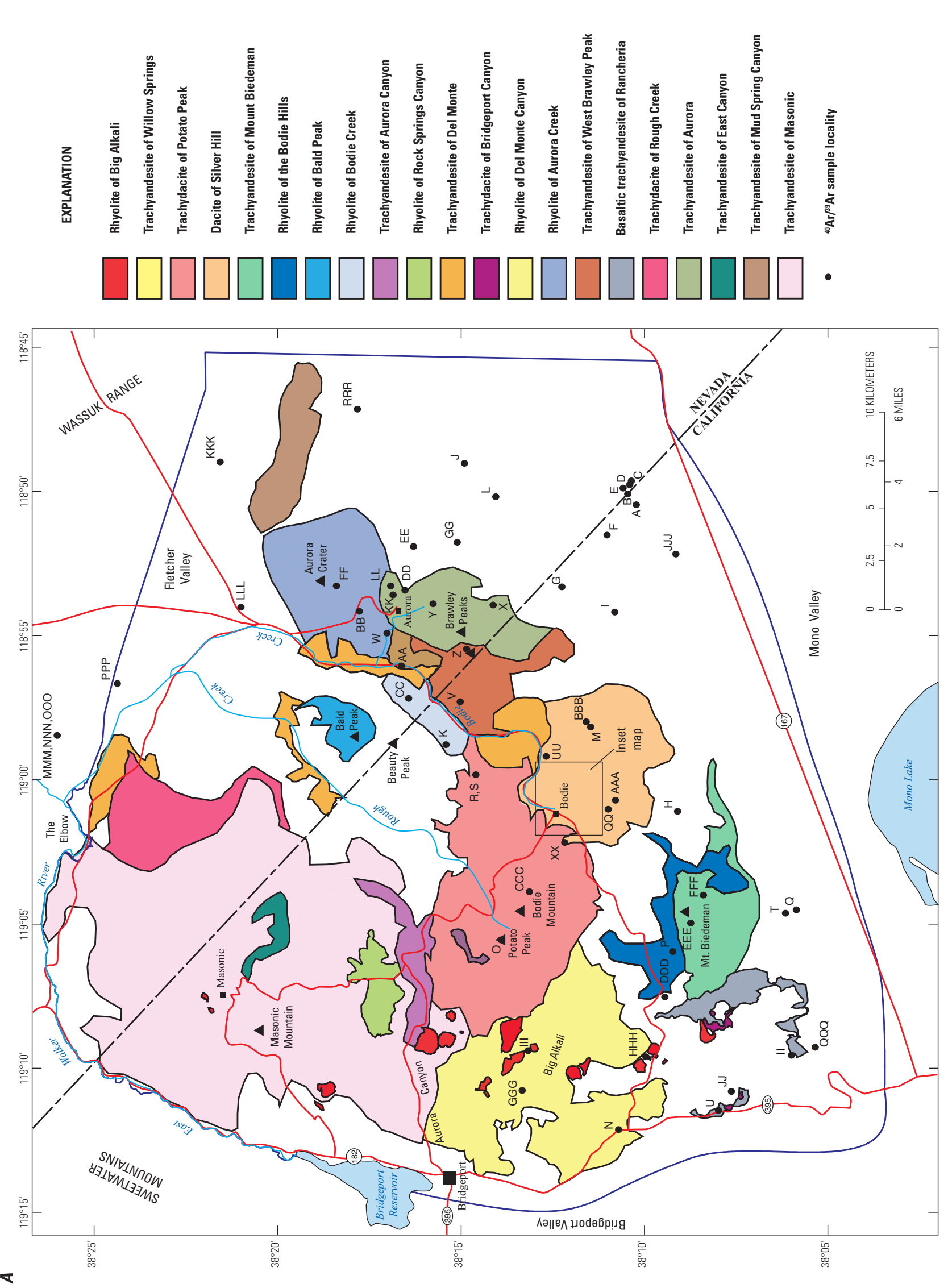

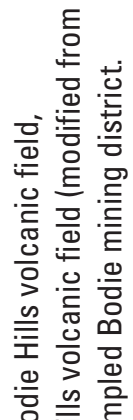
立号高

衣 产 ¿ั0 흏 E. $\stackrel{\Xi}{=}$ 음 음 票 बे 高. 它. 亭 ᄃ웡 交交 的资这 음 弄

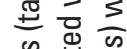
的离 을 은 言空 음 氡 응 긍 월 을

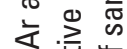

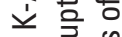
들 흔 은 娄语 造蓠 음 는 중 든 증 홍 흥 들 즡

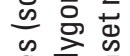
음 흐을 름으 娄 흥 $\frac{1}{5}$ 은 혼 产 资 文斻 ๓่ 鿷高高 


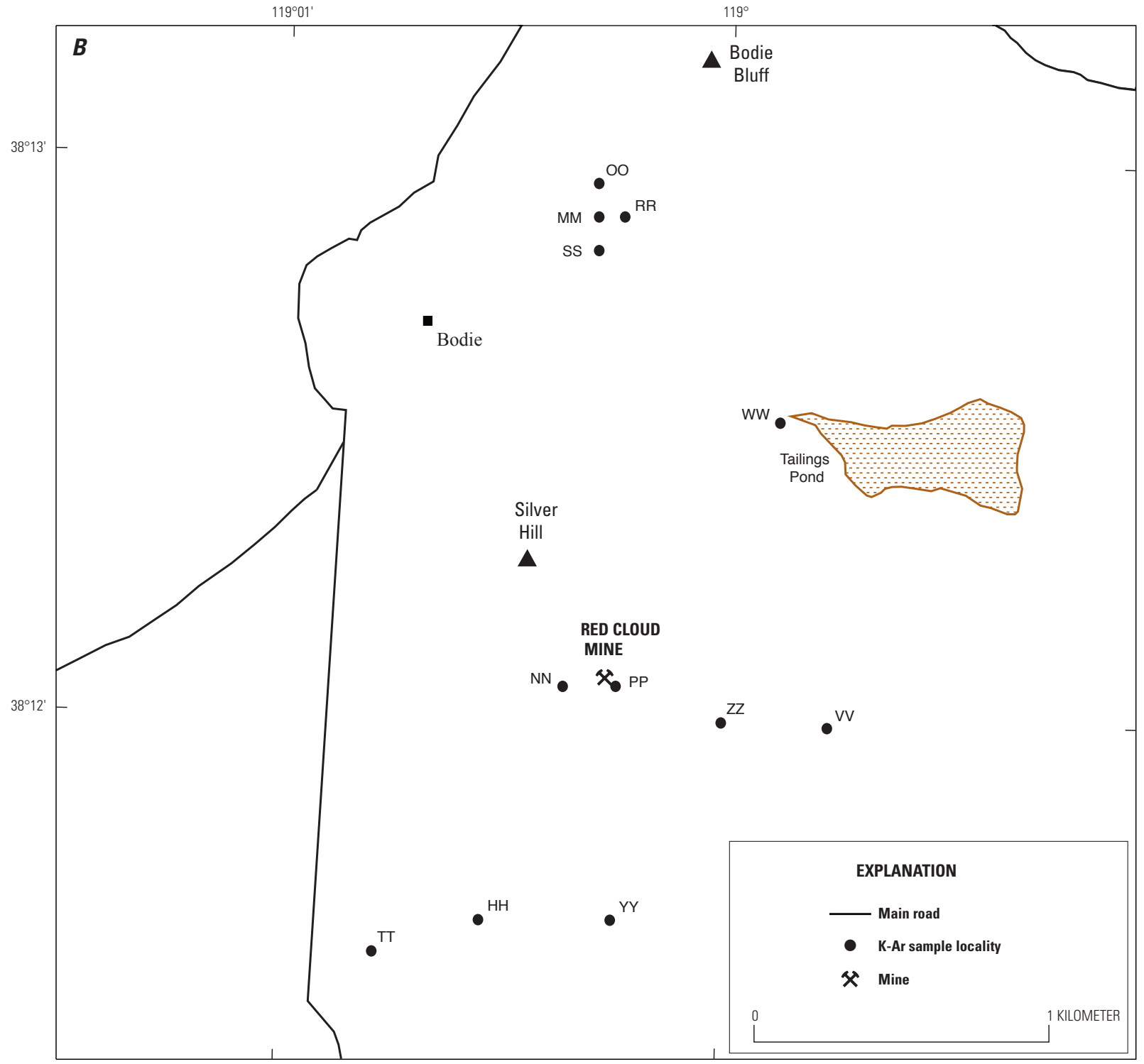

Figure 3.-Continued 


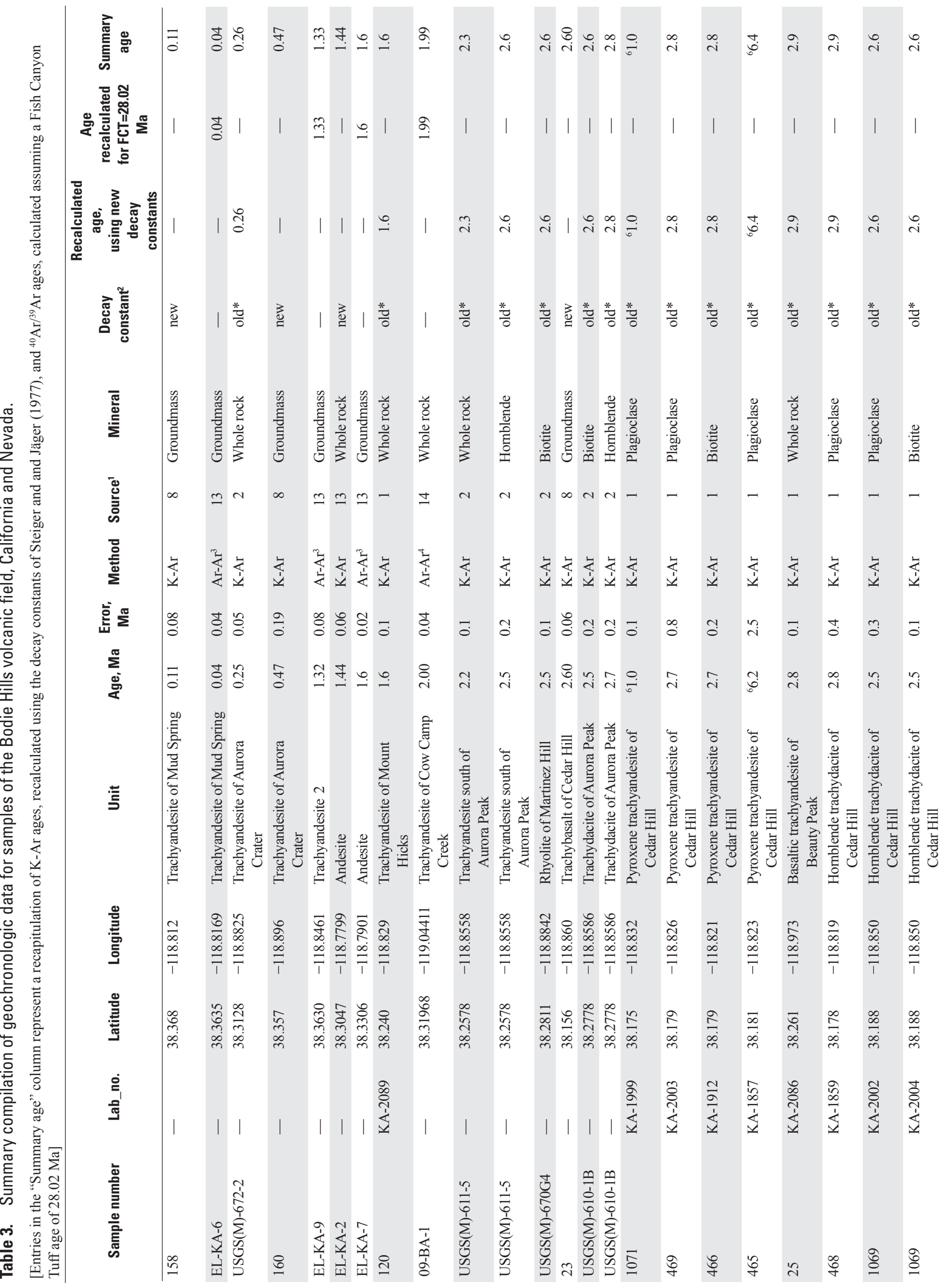




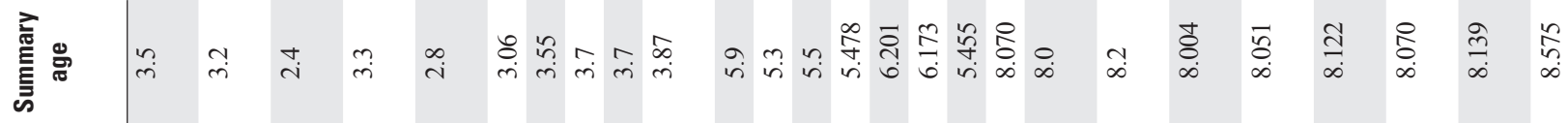

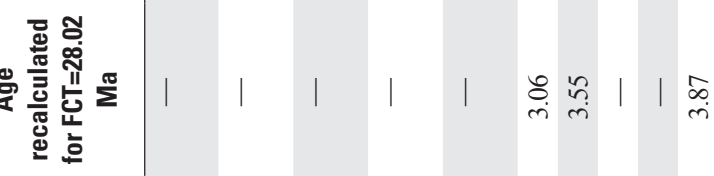

竞

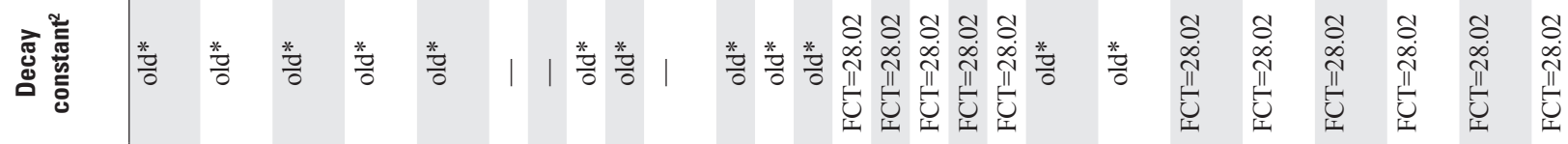

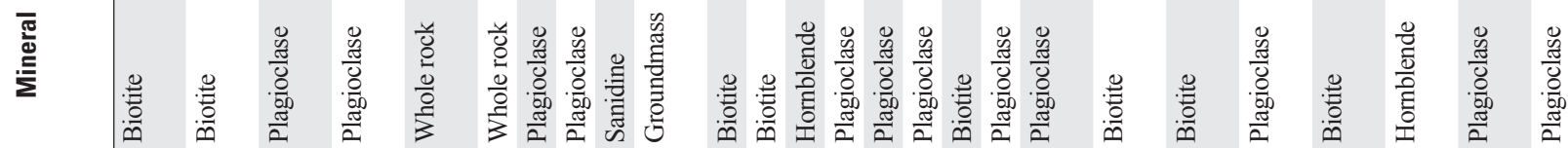

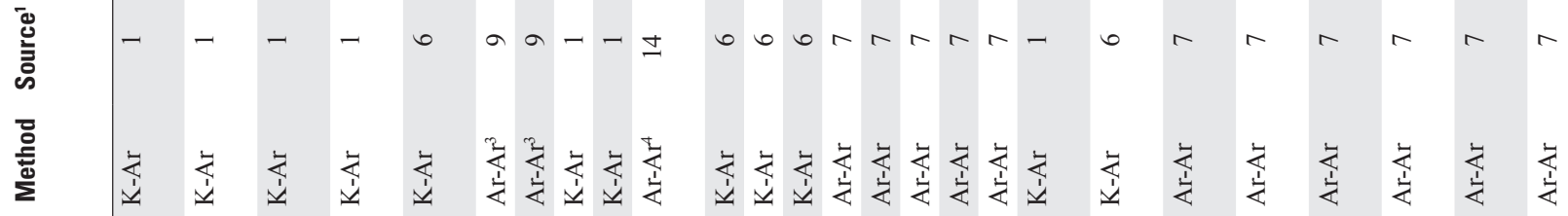

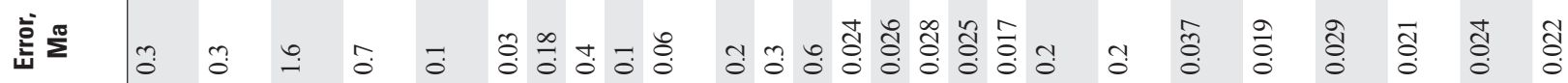

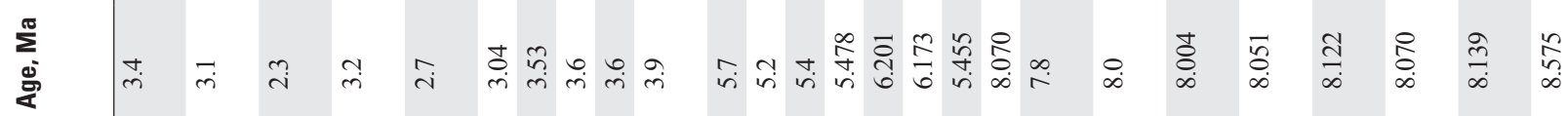

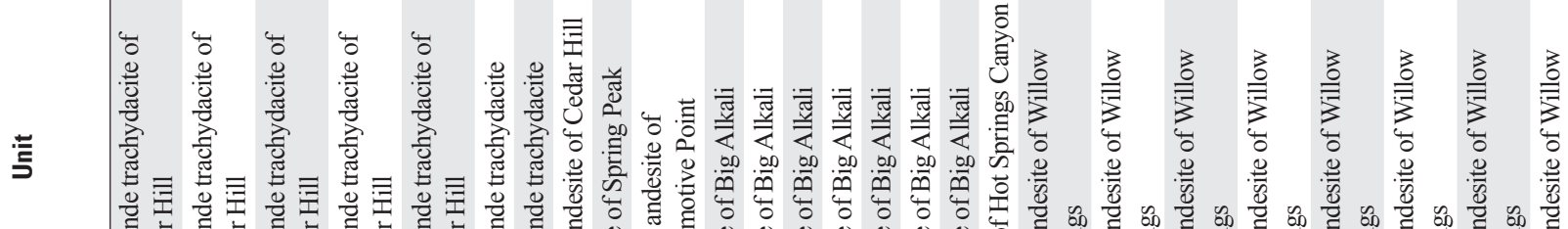

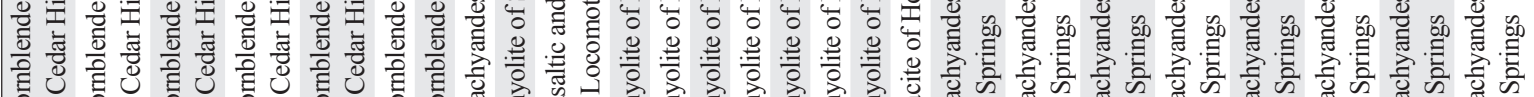

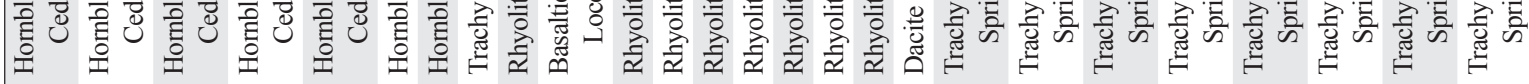

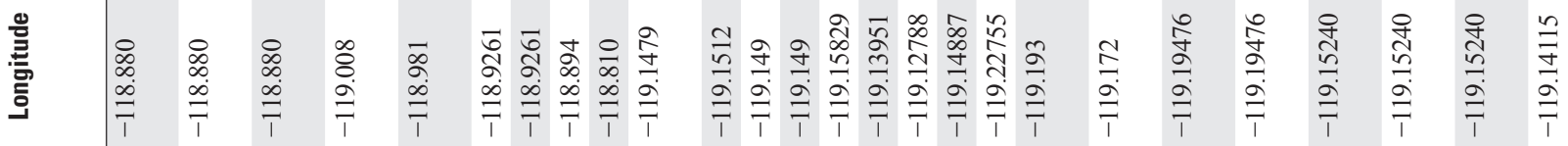

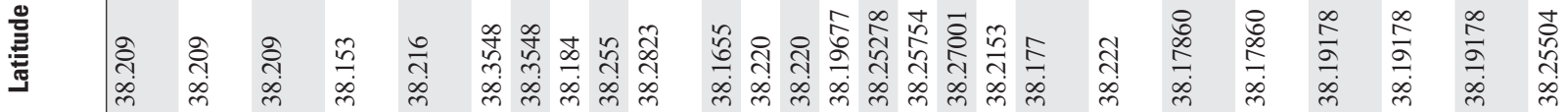

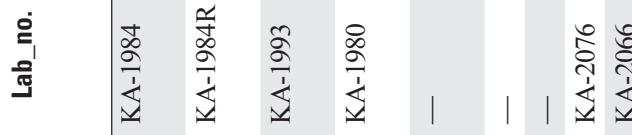

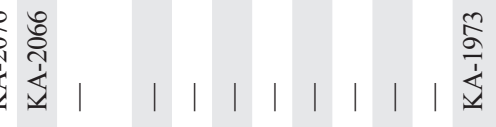

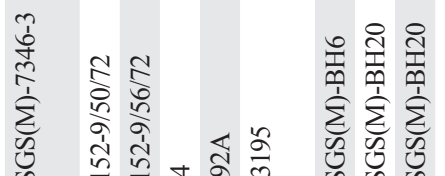

赵

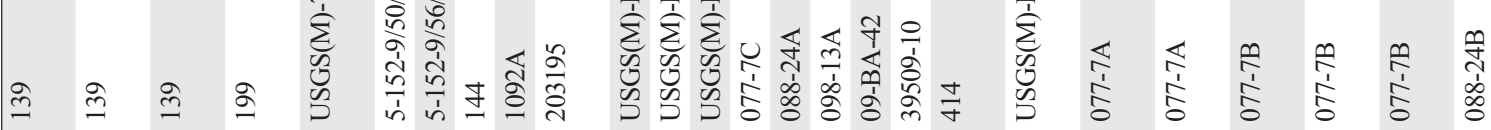




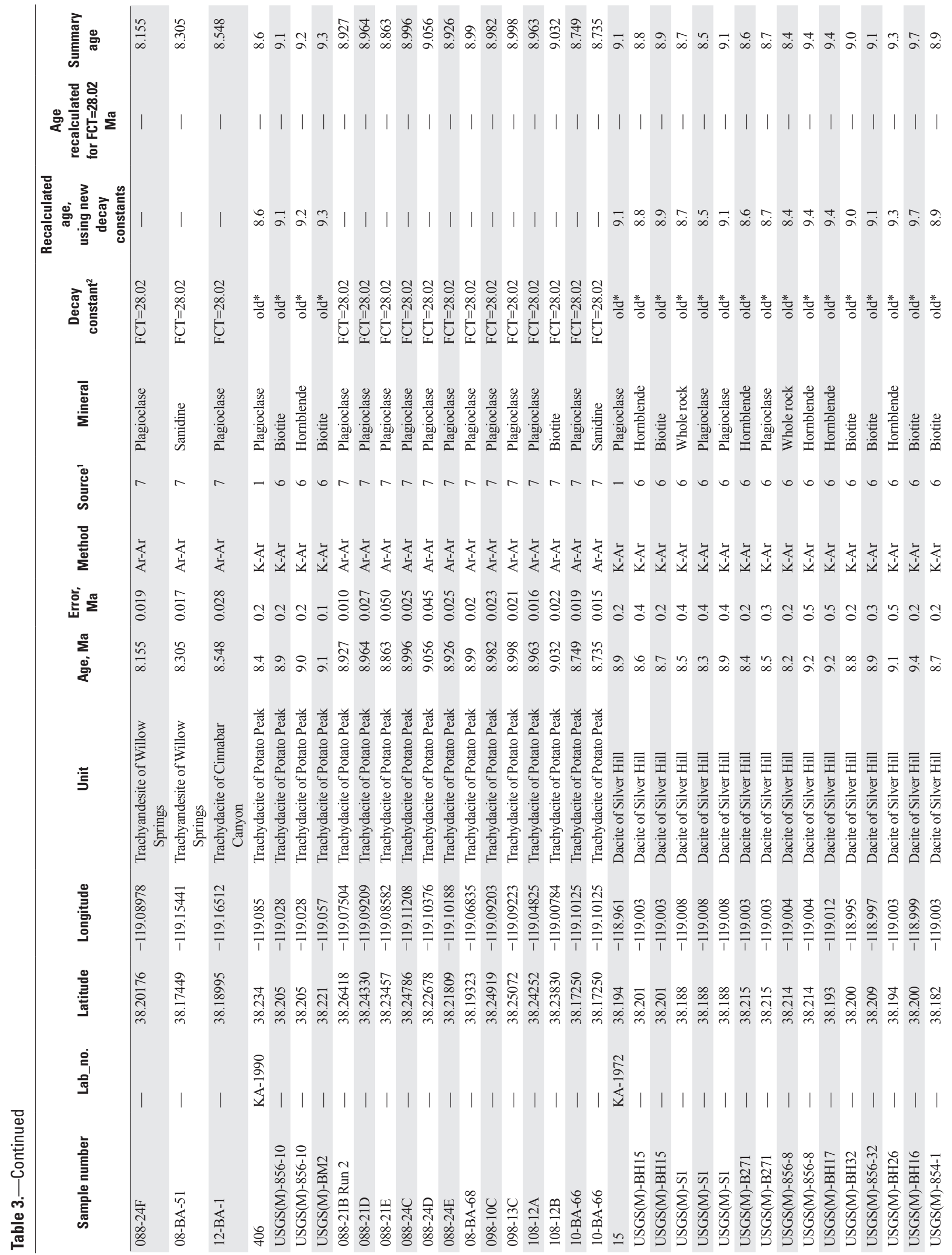




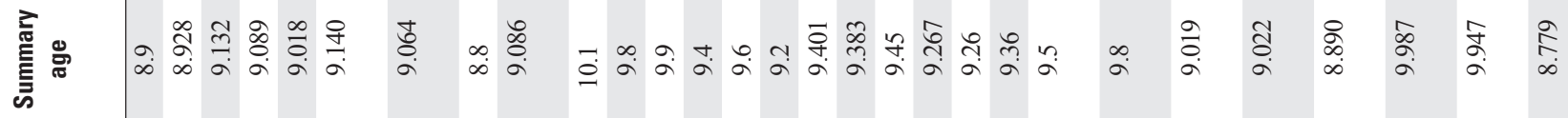

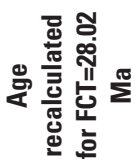

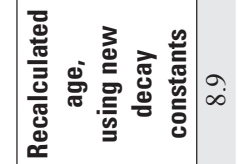

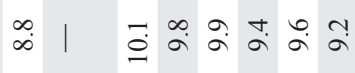

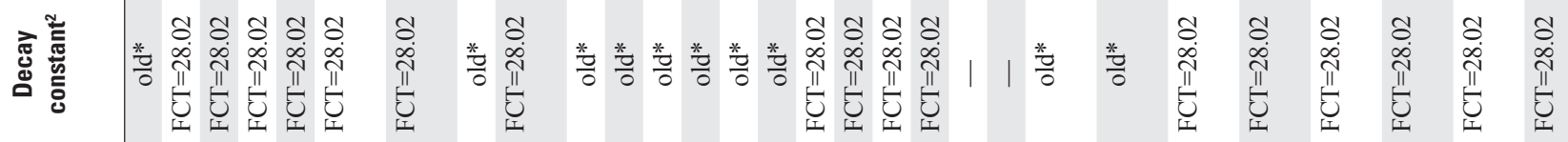

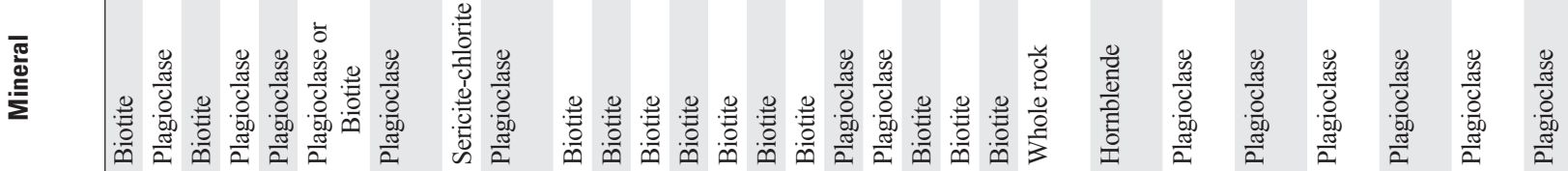

ì

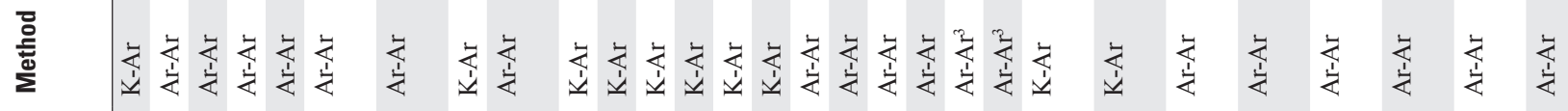

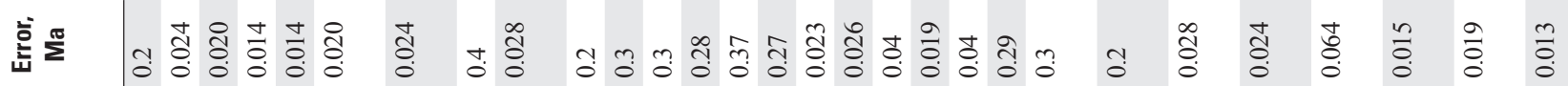

焉

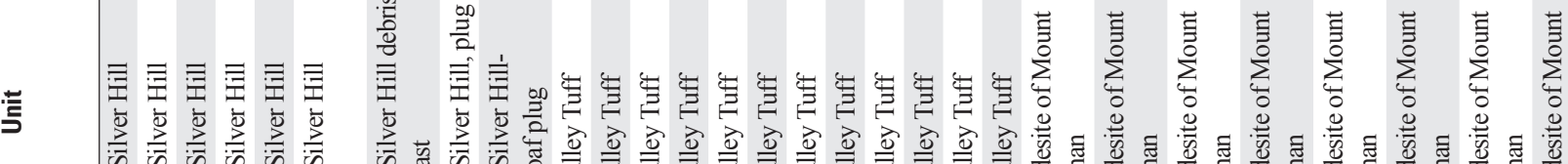

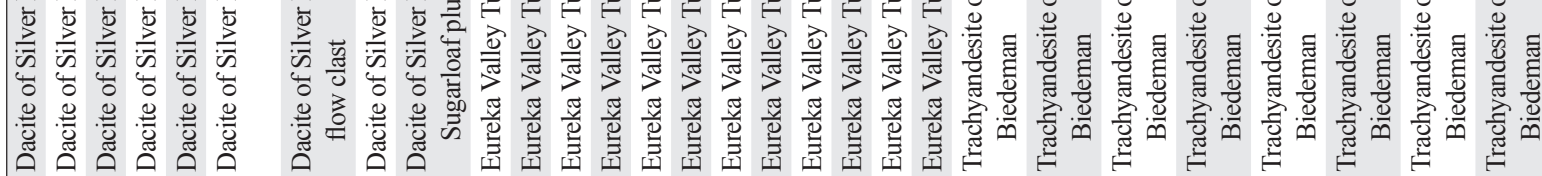

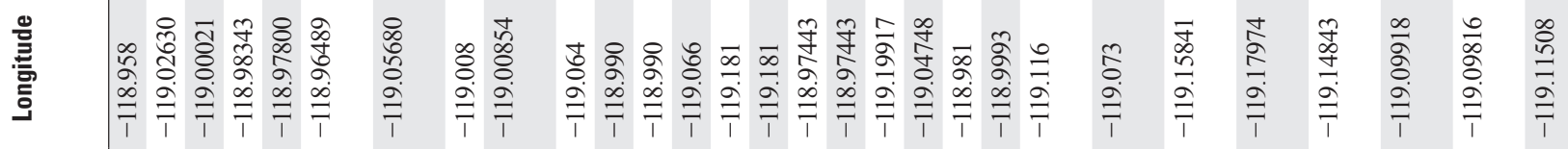

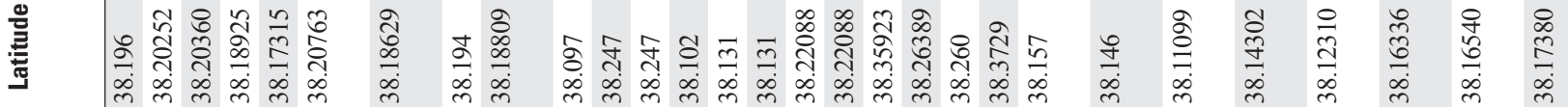

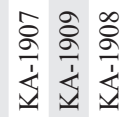

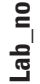

藏

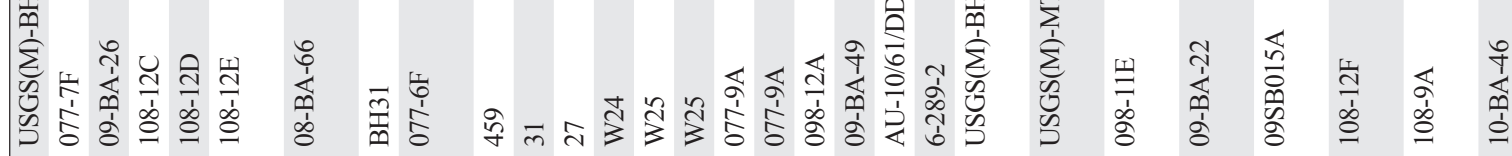




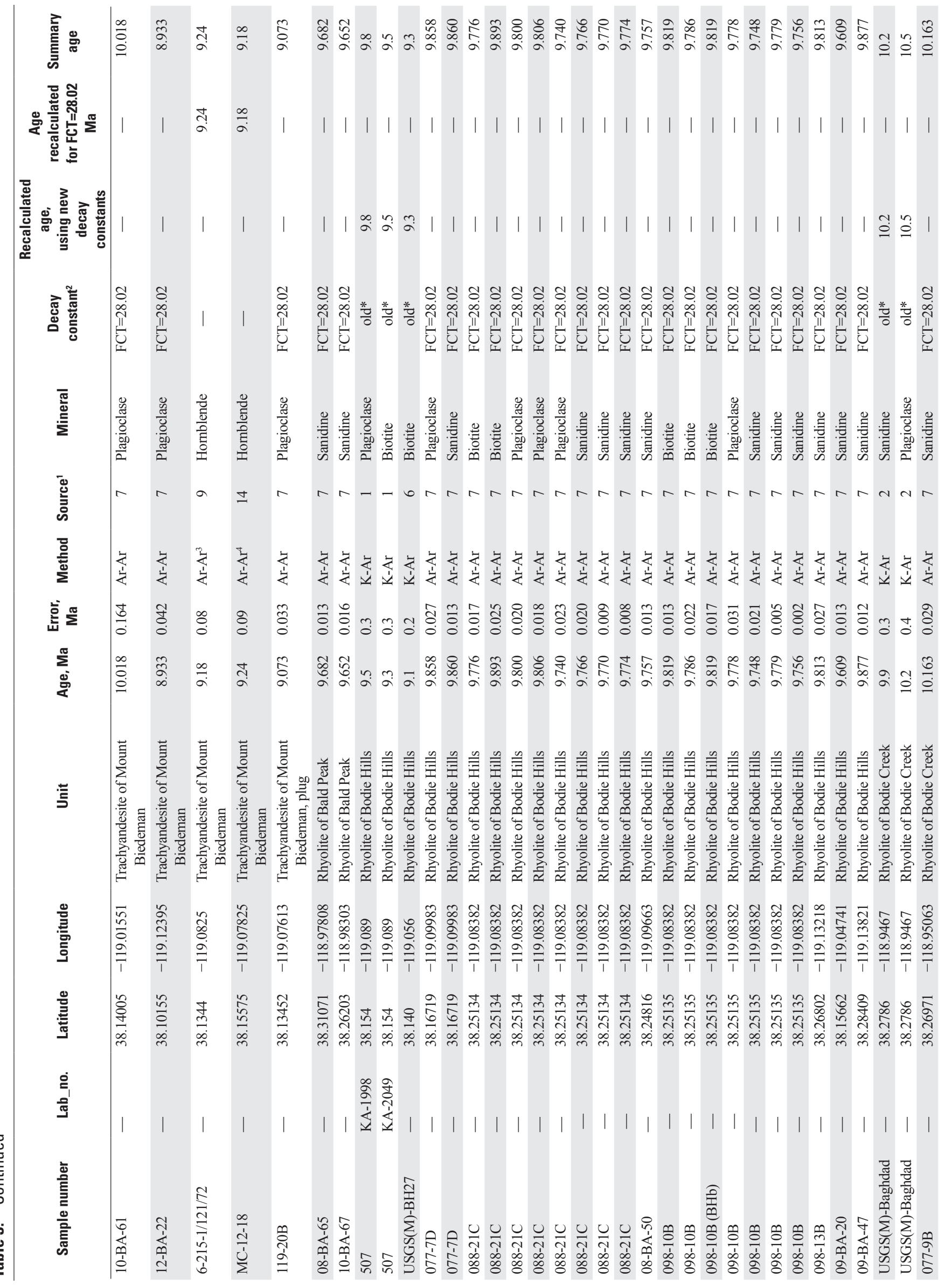




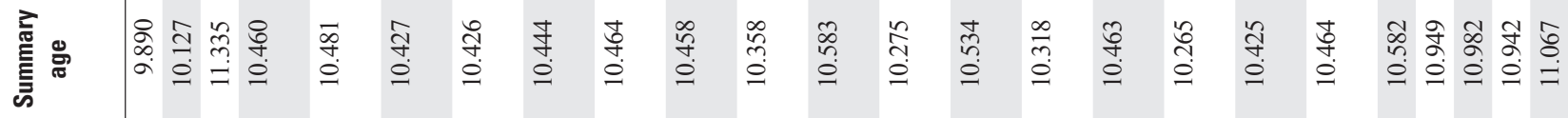

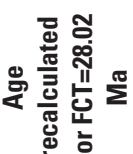

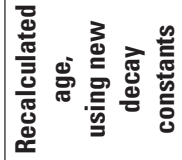

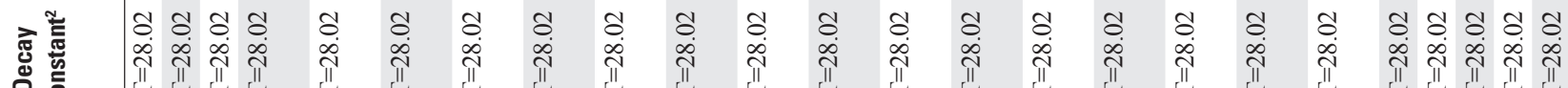

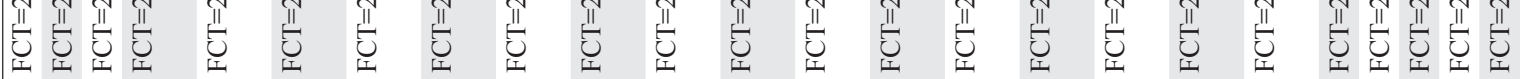

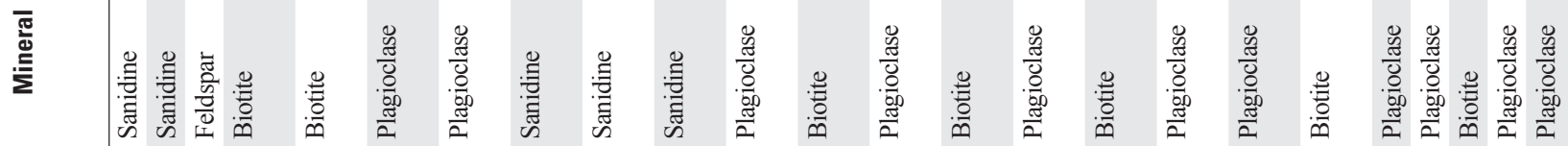
兽

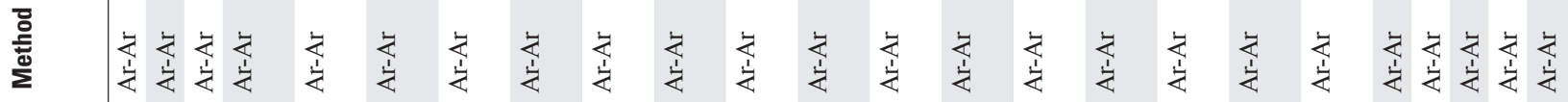
竎功

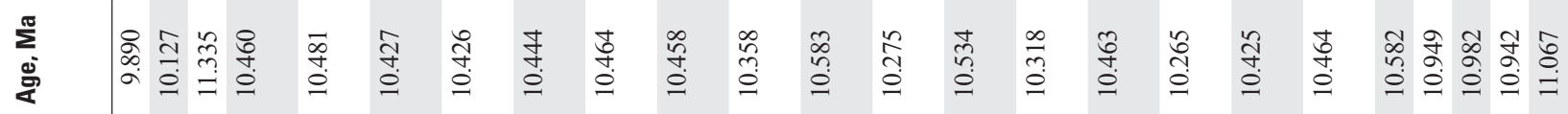

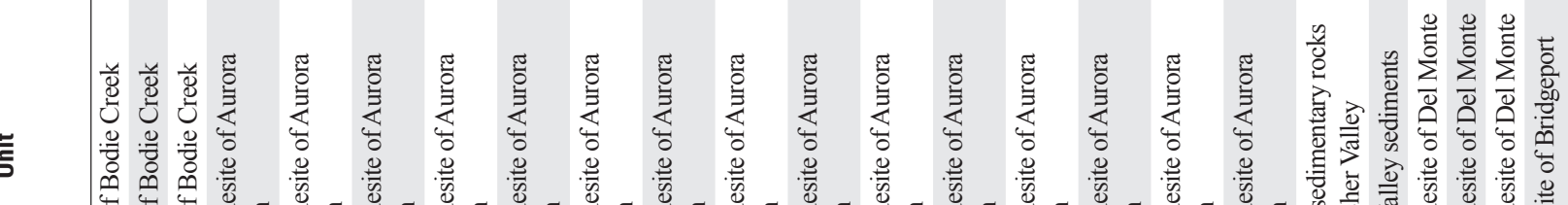

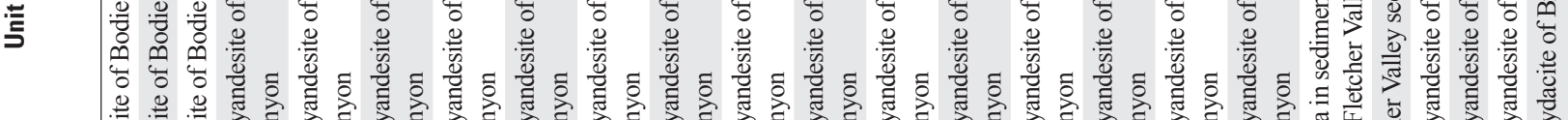

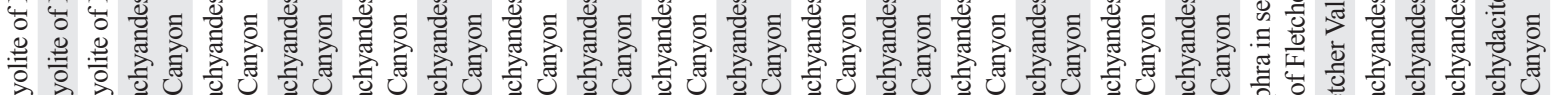

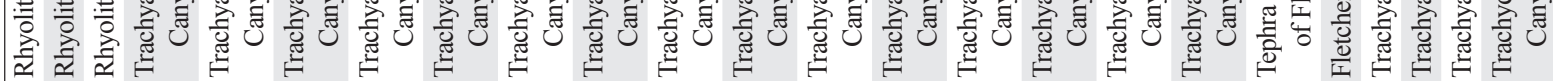

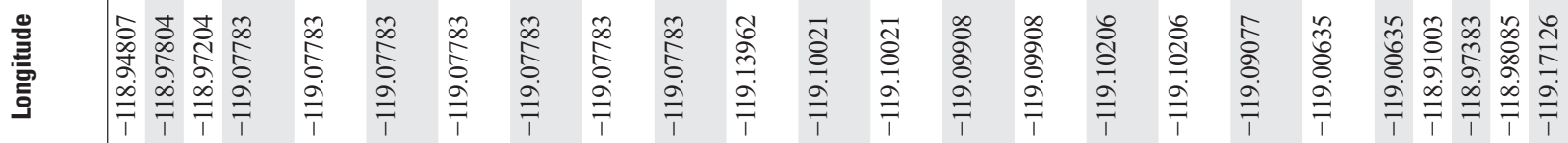

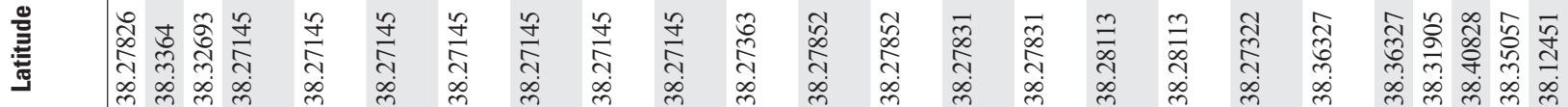

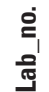




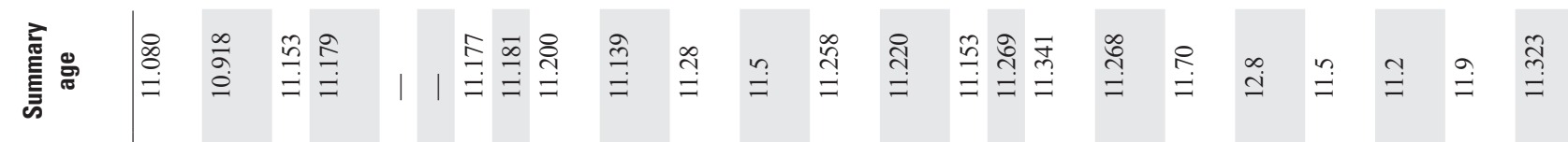

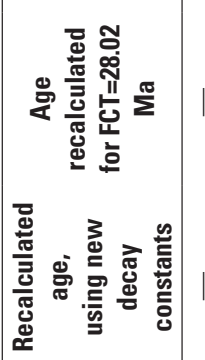

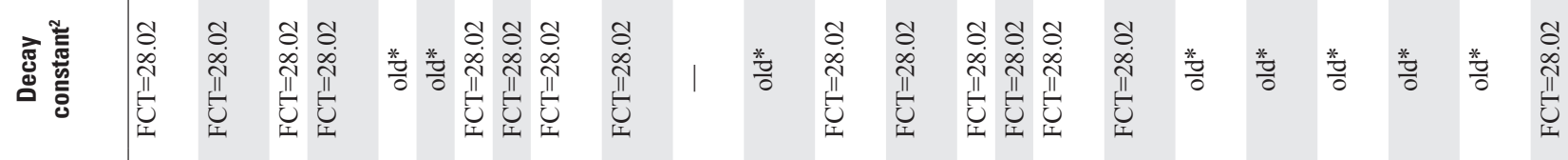

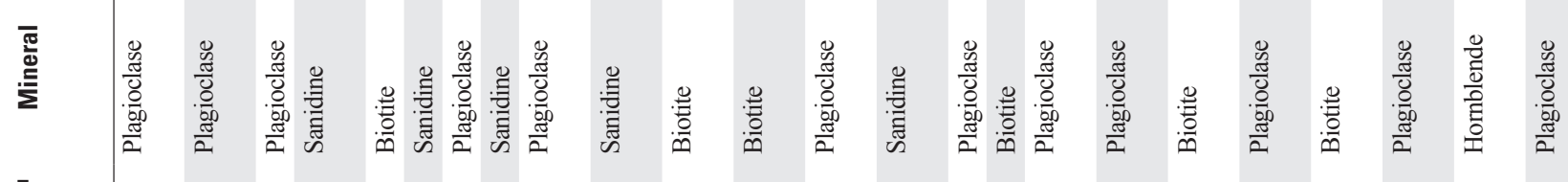

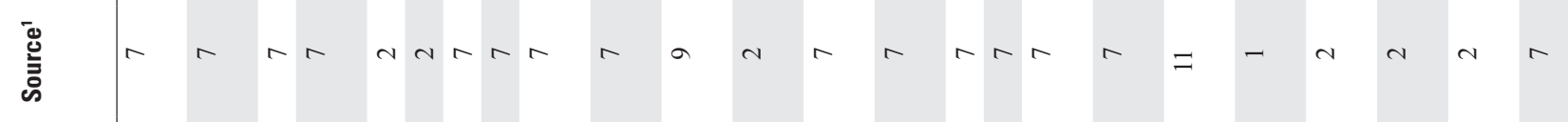

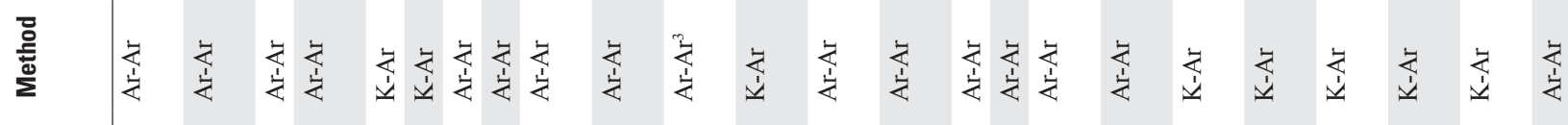

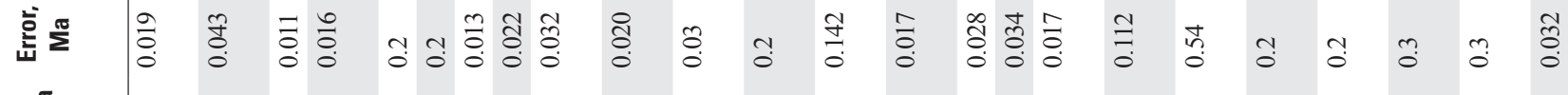

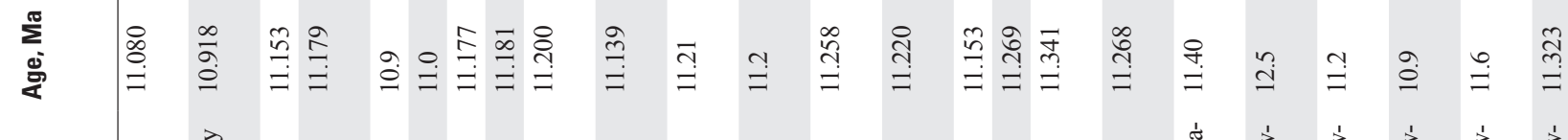

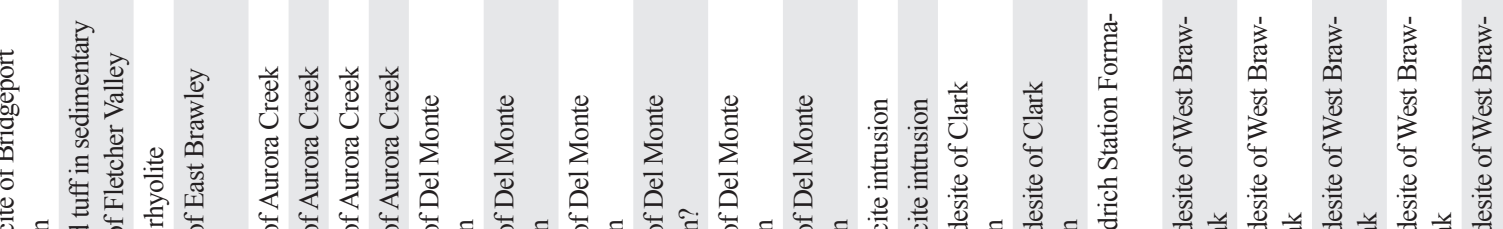

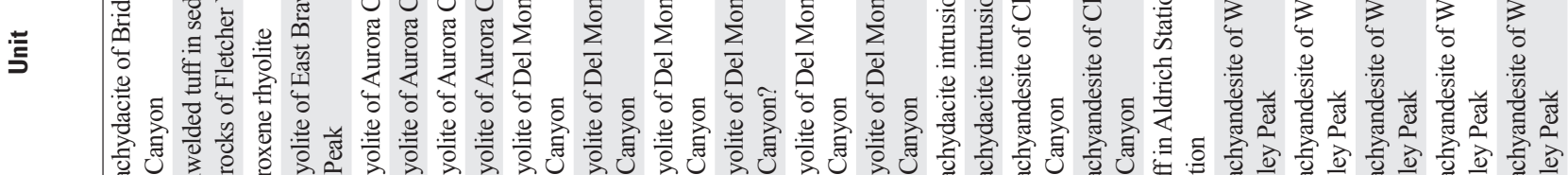

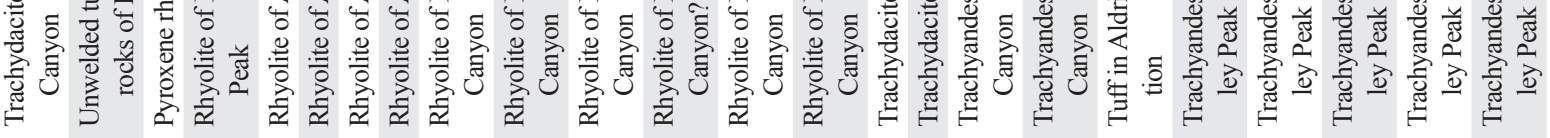

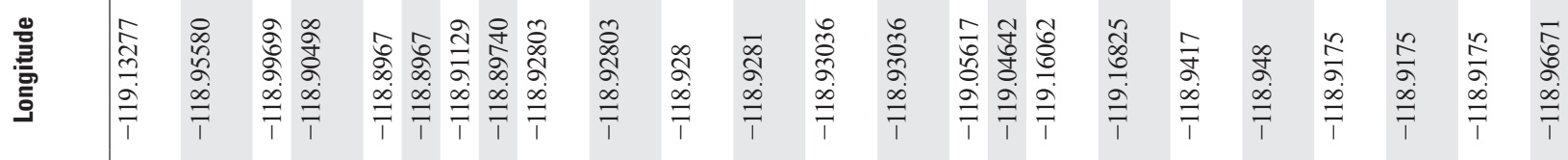

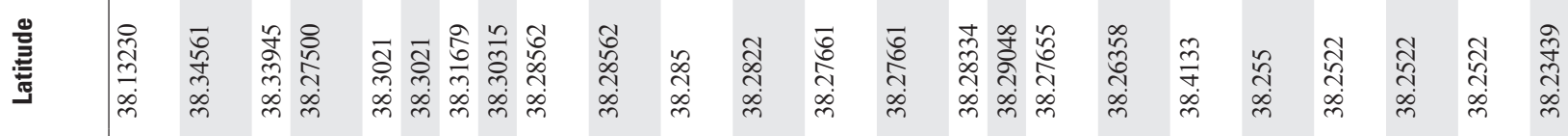


Table III 21

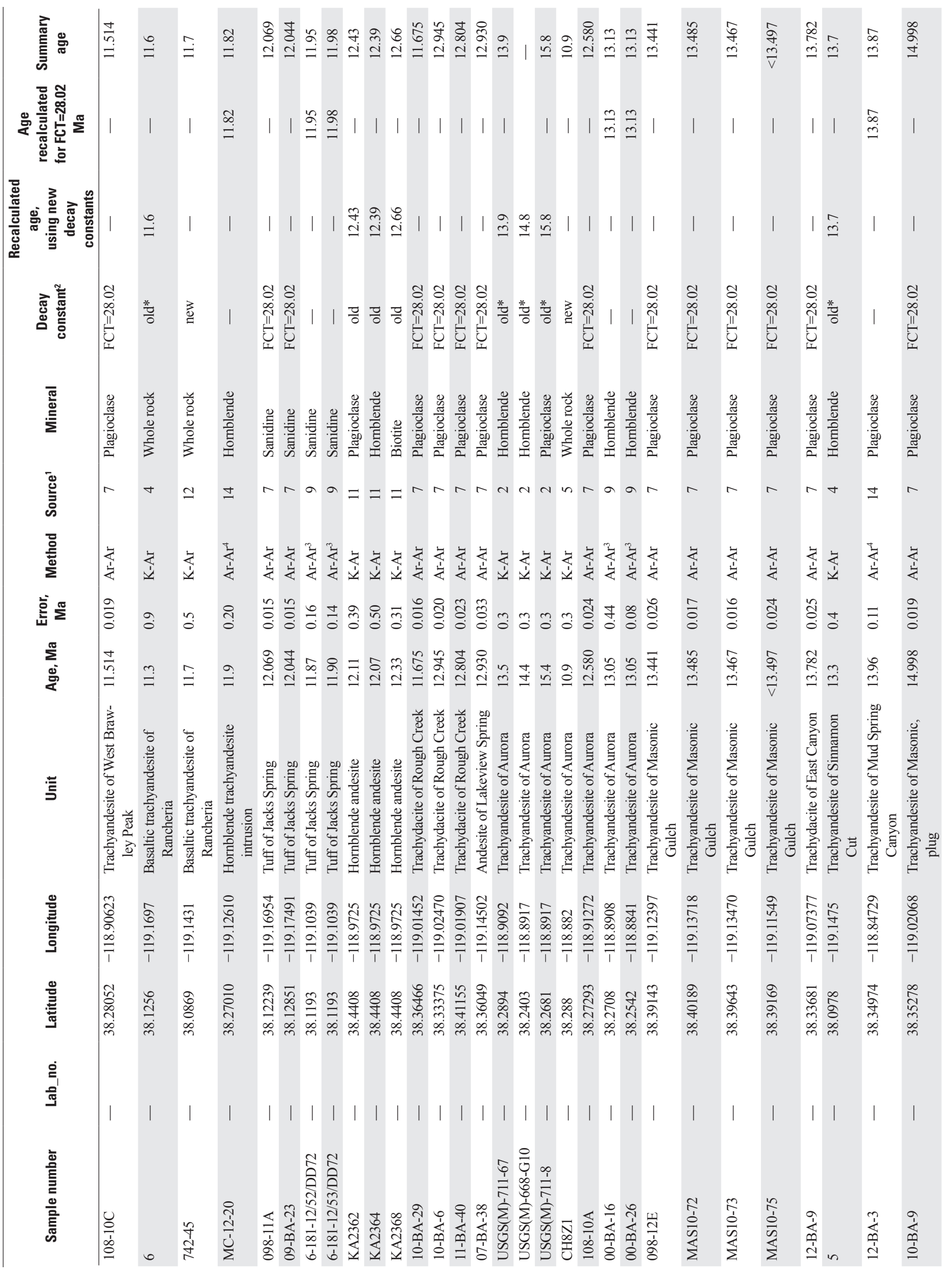




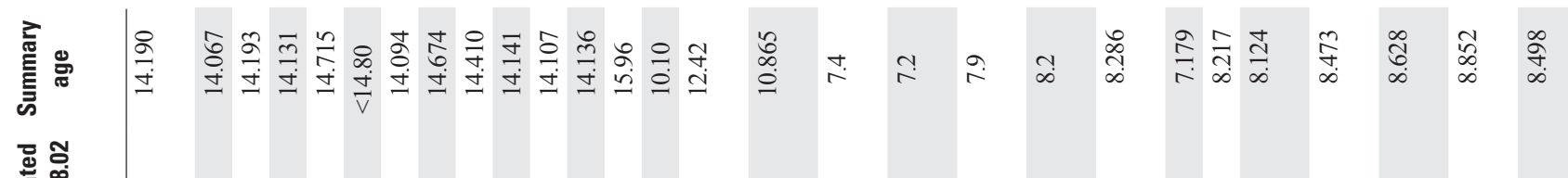

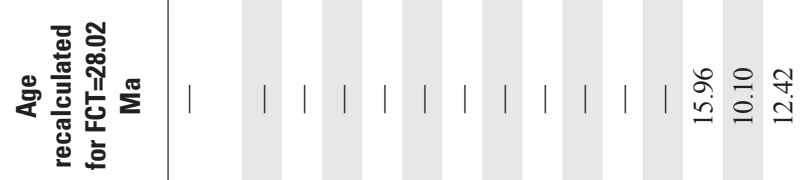

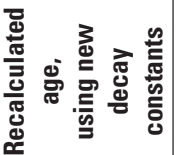

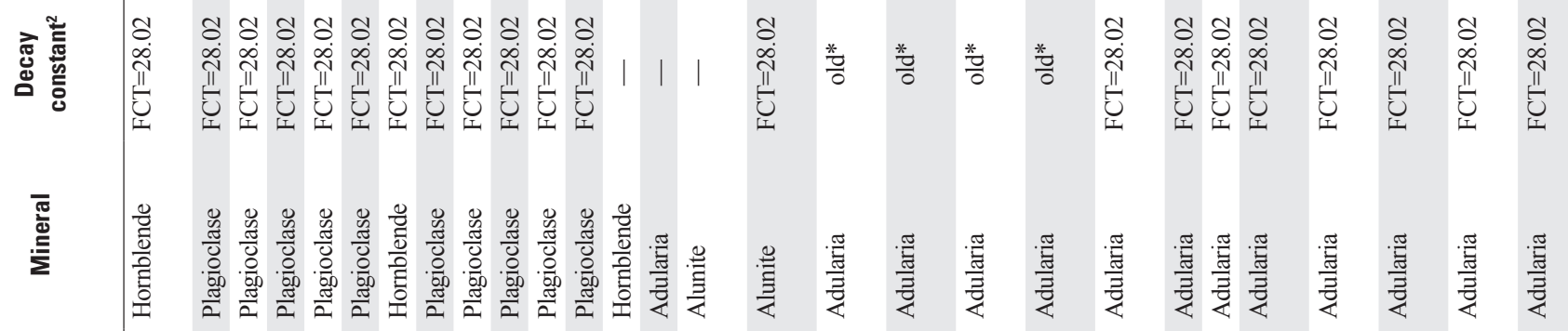
¿ః.

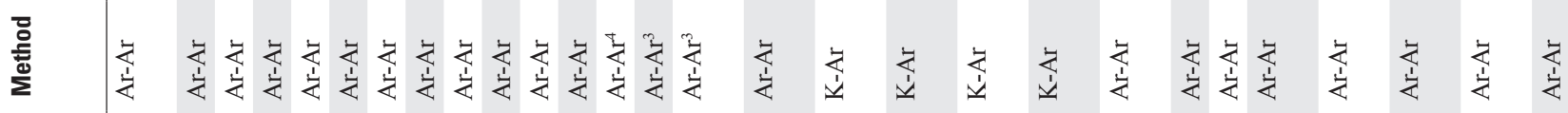

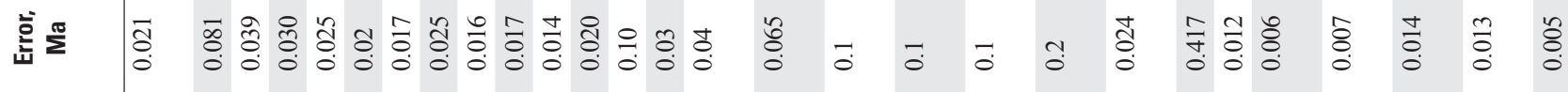

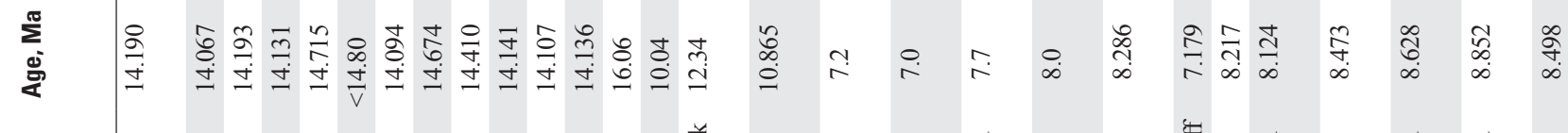

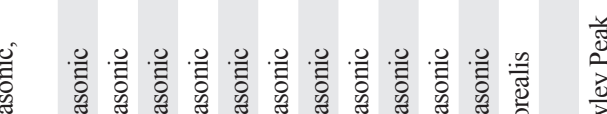

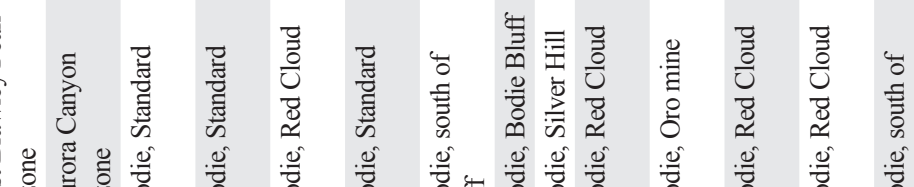

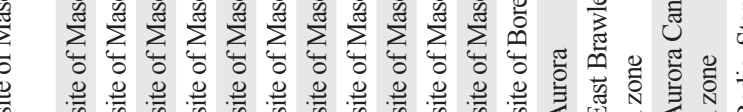

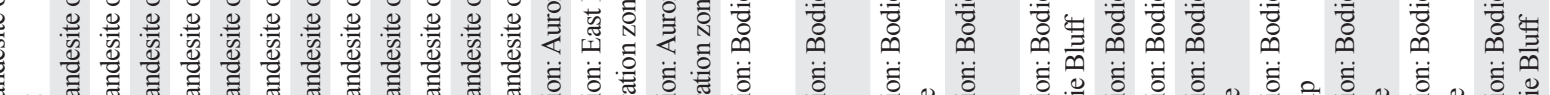

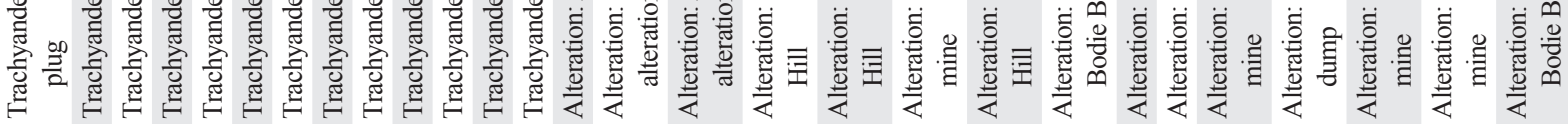




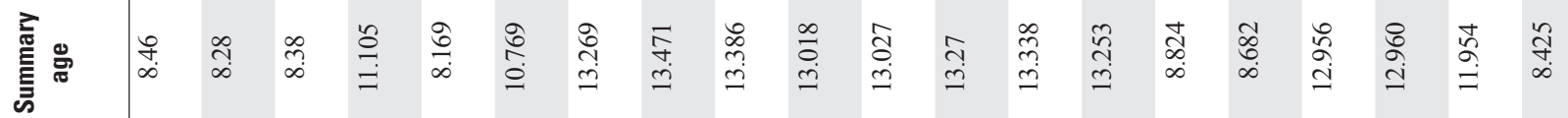

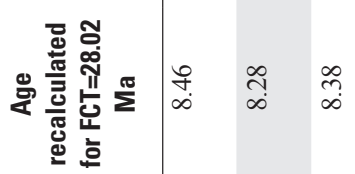

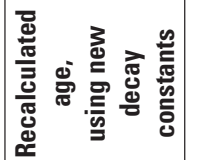

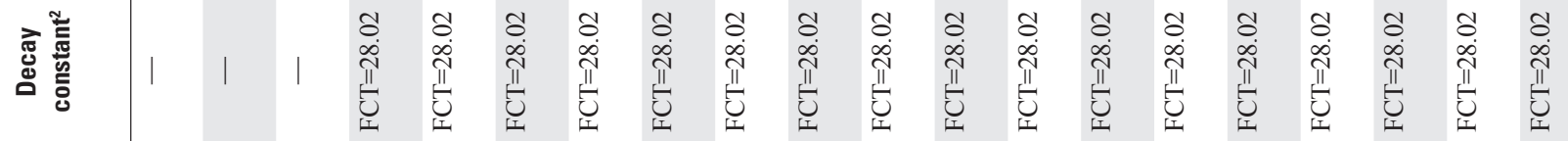

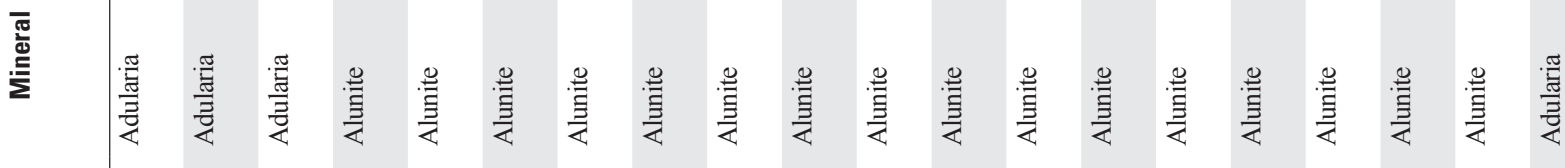

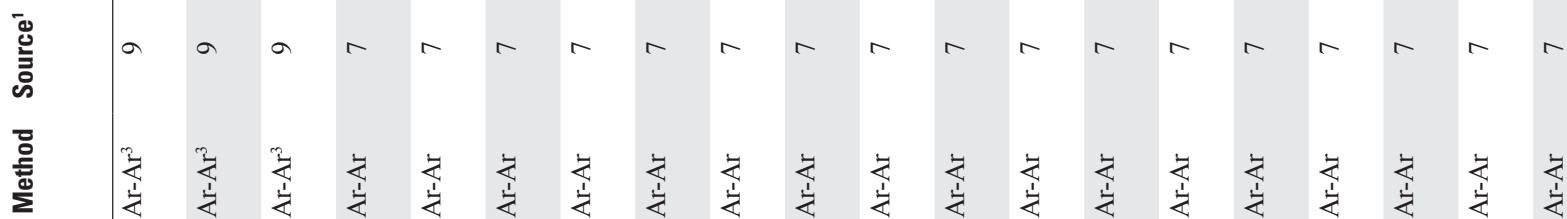

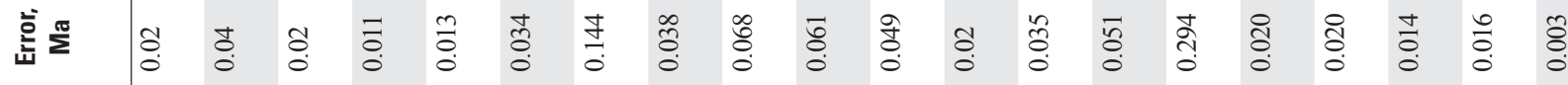

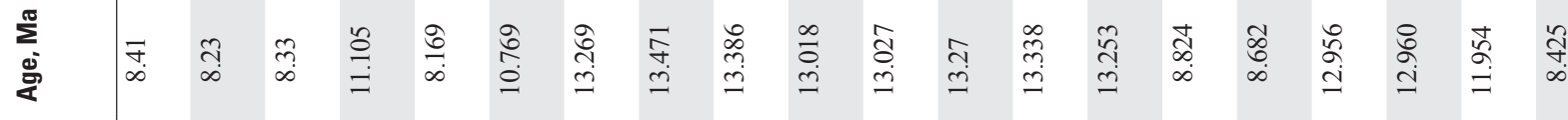

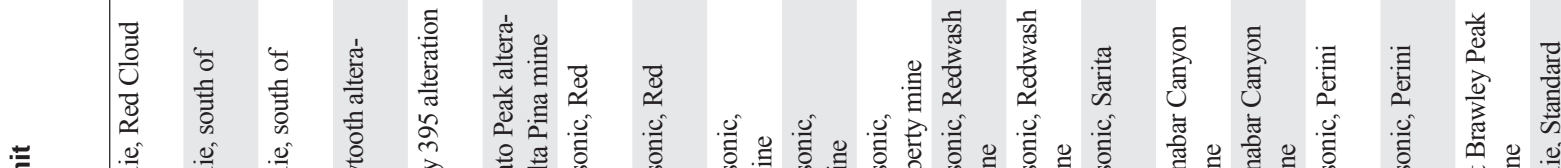

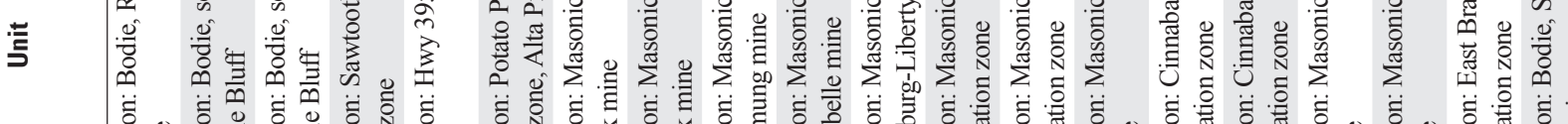

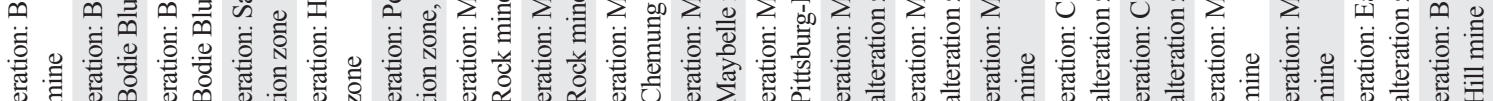

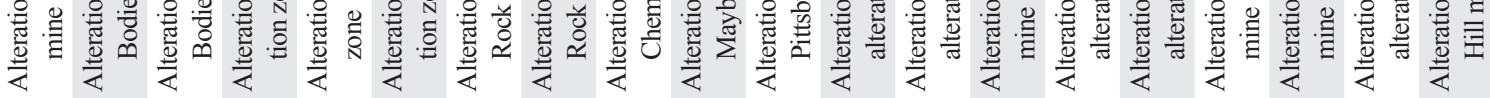

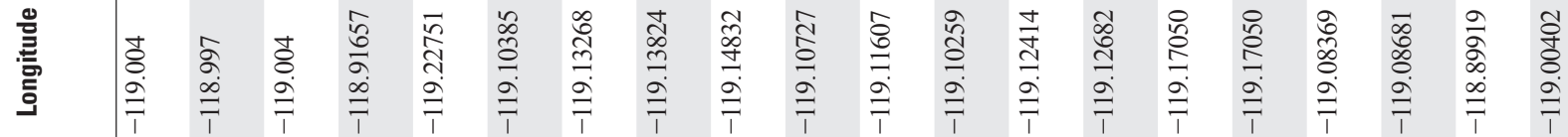

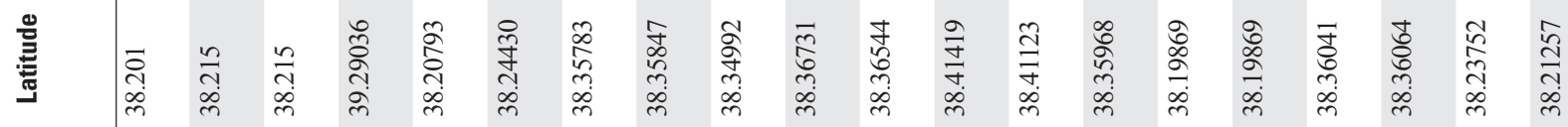

ت 


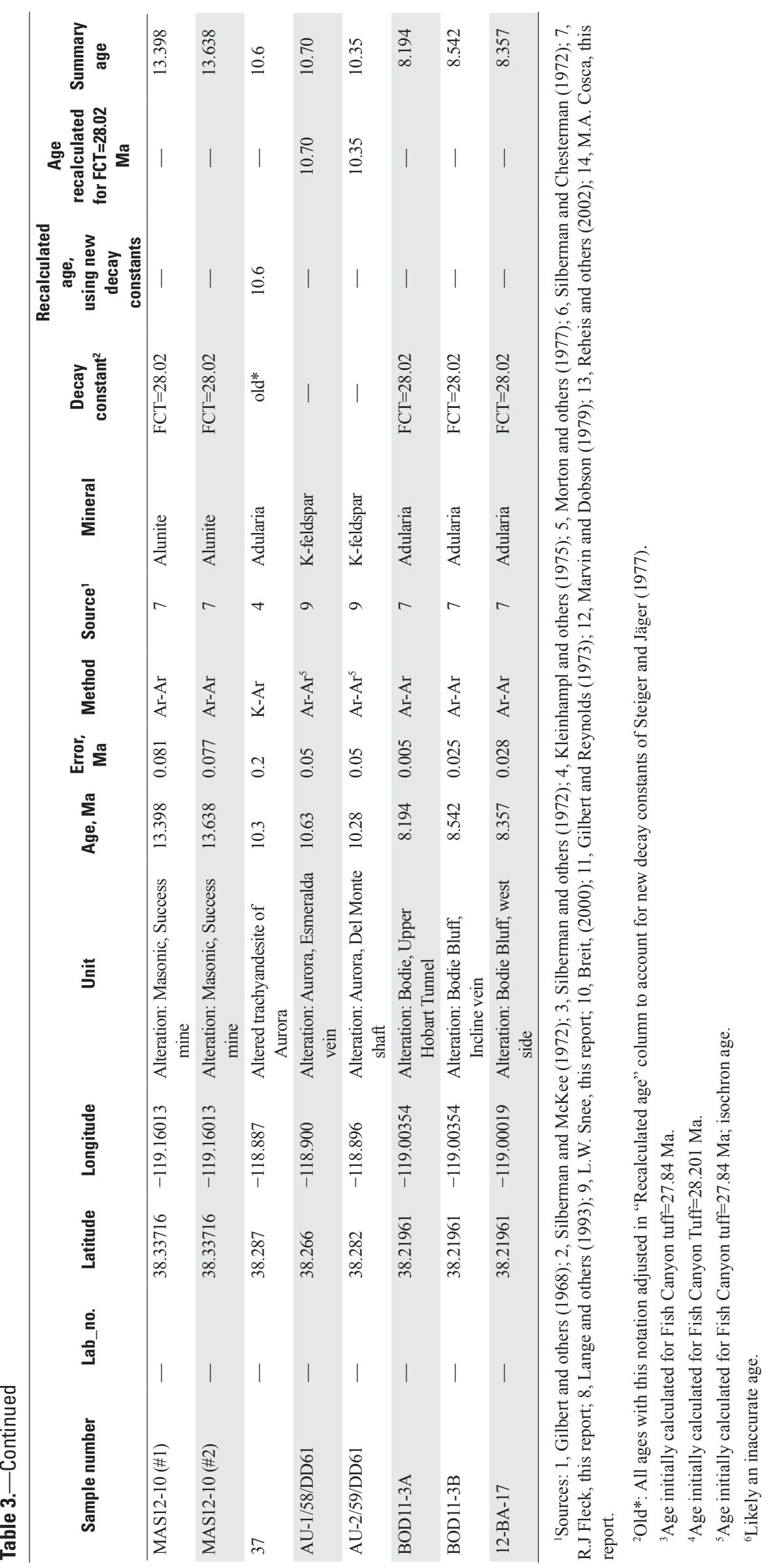




\section{References Cited}

Al-Rawi, Y.T., 1969, Cenozoic history of the northern part of Mono Basin, California and Nevada: Berkeley, University of California, Ph.D. dissertation, 163 p.

Breit, F.J., Jr., 2000, Structural and temporal relationships and geochemical characteristics of the East Brawley Peak acidsulfate prospect and the adjacent Aurora adularia-sericite system: Reno, University of Nevada, M.S. thesis, 215 p.

Busby, C.J., 2013, Birth of a plate boundary at ca. $12 \mathrm{Ma}$ in the Ancestral Cascades arc, Walker Lane belt of California and Nevada: Geosphere, v. 9, p. 1147-1160.

Carlson, C.W., Pluhar, C.J., Glen, J.M.G., and Farner, M.J., 2013, Kinematics of the west-central Walker LaneSpatially and temporally variable rotations evident in the late Miocene Stanislaus Group: Geosphere, v. 9, p. $1530-1551$.

Chesterman, C.W., and Gray, C.H., Jr., 1975, Geology of the Bodie 15-minute quadrangle, Mono County, California: California Division of Mines and Geology, Map Sheet 21, scale 1:48,000.

Dalrymple, G.B., Alexander, B.C., Lanphere, M.A., and Kraker, G.P, 1981, Irradiation of samples for ${ }^{40} \mathrm{Ar} /{ }^{39} \mathrm{Ar}$ dating using the Geological Survey TRIGA reactor: U.S. Geological Survey Professional Paper 1176, 55 p.

Dalrymple, G.B., and Lanphere, M.A., 1969, Potassiumargon dating_-principles, techniques and applications to geochronology: San Francisco, Freeman, 258 p.

du Bray, E.A., John, D.A., and Cousens, B.L., 2014, Petrologic, tectonic, and metallogenic evolution of the southern segment of the ancestral Cascades magmatic arc, California and Nevada: Geosphere, v. 10, p. 1-39.

Faulds, J.E., and Henry, C.D., 2008, Tectonic influences on the spatial and temporal evolution of the Walker Lane-An incipient transform fault along the evolving Pacific - North American plate boundary, in Spencer, J.E., and Titley, S.R., eds., Ores and orogenesis: Circum-Pacific tectonics, geologic evolution, and ore deposits: Arizona Geological Society Digest 22, p. 437-470.

Fleck, R.J., Hagstrum, J.T., Calvert, A.T., and Evarts, R.C., $2014,{ }^{40} \mathrm{Ar} /{ }^{39} \mathrm{Ar}$ geochronology, paleomagnetism, and evolution of the Boring volcanic field, Oregon and Washington, USA: Geosphere, v. 10, no. 6, p. 1283-1314, doi:10.1130/ GES00985.1

Fleck, R.J., Sutter, J.H., and Elliot, D.H., 1977, Interpretation of discordant ${ }^{40} \mathrm{Ar} /{ }^{39} \mathrm{Ar}$ age-spectra of Mesozoic tholeiites from Antarctica: Geochimica et Cosmochimica Acta, v. 41, p. 15-32.
Gilbert, C.M., Christiansen, M.N., Al-Rawi, Yehya, and Lajoie, K.R., 1968, Structural and volcanic history of Mono Basin, California-Nevada, in Coats, R.R., Hay, R.L., and Anderson, C.A., eds., Studies in Volcanology: Geological Society of America Memoir 116, p. 275-329.

Gilbert, C.M., and Reynolds, M.W., 1973, Character and chronology of basin development, western margin of the Basin and Range Province: Geological Society of America Bulletin, v. 84, p. 2489-2510.

Gill, J., 1981, Orogenic andesites and plate tectonics: New York, Springer-Verlag, 390 p.

John, D.A., du Bray, E.A., Box, S.E., Vikre, P.G., Rytuba, J.J., Fleck, R.J., and Moring, B.C., 2015, Geologic map of the Bodie Hills, California and Nevada: U.S. Geological Survey Scientific Investigations Map 3318, 64 p., 2 sheets, scale 1:50,000, http://dx.doi.org/10.3133/sim3318.

John, D.A., du Bray, E.A., Fleck, R.J., Vikre, P.G., Box, S.E., and Moring, B.C., 2012, Miocene magmatism in the Bodie Hills volcanic field, California and Nevada-A long-lived eruptive center in the southern segment of the ancestral Cascades arc: Geosphere, v. 8, p. 44-97.

Kingdon, S., Cousens, B., John, D.A., and du Bray, E.A., 2013, Pliocene to late Pleistocene magmatism in the Aurora Volcanic Field, Nevada and California, USA [abs.]: Eos Transactions AGU V13G-2700.

Kleinhampl, F.J., Davis, W.E., Silberman, M.L., Chesterman, C.W., Chapman, R.H., and Gray, C.H., Jr., 1975, Aeromagnetic and limited gravity studies and generalized geology of the Bodie Hills region, Nevada and California: U.S. Geological Survey Bulletin 1384, 38 p.

Kuiper, K.F., Deino, A., Hilgen, F.J., Krijgsman, W., Renne, P.R., and Wijbrans, J.R., 2008, Synchronizing rock clocks of Earth history: Science, v. 320, p. 500-504.

Lange, R.A., and Carmichael, I.S.E., 1996, The Aurora volcanic field, California-Nevada-Oxygen fugacity constraints on the development of andesitic magma: Contributions to Mineralogy and Petrology, v. 125, p. 167-185.

Lange, R.A., Carmichael, I.S.E., and Renne, Paul, 1993, Potassic volcanism near Mono Basin, California-Evidence for high water and oxygen fugacities inherited from subduction: Geology, v. 21, p. 949-952.

Lee, J.-Y., Marti, K., Severinghaus, J.P., Kawamura, K., Yoo, H.-S., Lee, J.B., and Kim, J.S., 2006, A redetermination of the isotopic abundances of atmospheric Ar: Geochimica et Cosmochimica Acta, v. 70, p. 4507-4512.

Marvin, R.F., and Dobson, S.W., 1979, Radiometric ages; compilation B, U.S. Geological Survey: Isochron/West, no. 26, p. 3-30. 
McIntyre, G.A., Brooks, C., Compston, W., Turek, A., 1966, The statistical assessment of Rb-Sr isochrons: Journal of Geophysical Research, v. 71, p. 5459-5468.

Morton, J.L., Silberman, M.L., Bonham, H.F., Jr., Garside, L.J., and Noble, D.C., 1977, K-Ar ages of volcanic rocks, plutonic rocks, and ore deposits in Nevada and eastern California; determinations run under the USGS-NBMG Cooperative Program: Isochron/West, no. 20, p. 19-29.

Oldow, J.S., 1992, Late Cenozoic displacement partitioning in the northwestern Great Basin, in Craig, S.D., ed., Structure, tectonics, and mineralization of the Walker Lane; Walker Lane Symposium, proceedings volume: Reno, Nevada, Geological Society of Nevada, p. 17-52.

Oldow, J.S., 2003, Active transtensional boundary zone between the western Great Basin and Sierra Nevada block, western U.S. Cordillera: Geology, v. 31, p. 1033-1036.

Reheis, M.C, Stine, Scott, and Sarna-Wojcicki, A.M., 2002, Drainage reversals in Mono Basin during the late Pliocene and Pleistocene: Geological Society of America Bulletin, v. 114, p. 991-1006.

Renne, P.R., Swisher, C.C., Deino, A.L., Karner, D.B., Owens, T.L., and DePaolo, D.J., 1998, Intercalibration of standards, absolute ages and uncertainties in ${ }^{40} \mathrm{Ar} /{ }^{39} \mathrm{Ar}$ dating: Chemical Geology, v. 145, p. 117-152.

Roddick, J.C., 1983, High precision intercalibration of ${ }^{40} \mathrm{Ar} /{ }^{39} \mathrm{Ar}$ standards: Geochimica et Cosmochimica Acta, v. 47 , p. $887-898$.

Samson, S.D., and Alexander, E.G., 1987, Calibration of interlaboratory ${ }^{40} \mathrm{Ar} /{ }^{39} \mathrm{Ar}$ dating standard $\mathrm{MMhb}-1$ : Isotope Geoscience, v. 66, p. 27-34.

Silberman, M.L., and Chesterman, C.W., 1972, K-Ar age of volcanism and mineralization, Bodie mining district and Bodie Hills volcanic field, Mono County, California: Isochron/West, no. 3, p. 13-22.
Silberman, M.L., Chesterman, C.W., Kleinhampl, F.J., and Gray, C.H., Jr., 1972, K-Ar ages of volcanic rocks and goldbearing quartz-adularia veins in the Bodie mining district, Mono County; California: Economic Geology, v. 67, p. 597-604.

Silberman, M.L., and McKee, E.H., 1972, A summary of radiometric age determinations on Tertiary volcanic rocks from Nevada and eastern California - part II, western Nevada: Isochron/West, no. 4, p. 7-28.

Snee, L.W., 2002, Argon thermochronology of mineral deposits - A review of analytical methods, formulations, and selected applications: U.S. Geological Survey Bulletin 2194, 39 p.

Steiger, R.H., and Jäger, E., 1977, Subcommission on geochronology - Convention on the use of decay constants in geo- and cosmochronology: Earth and Planetary Science Letters, v. 36, p. 359-362.

Stewart, J.H., 1988, Tectonics of the Walker Lane belt, western Great Basin-Mesozoic and Cenozoic deformation in a zone of shear, in Ernst, W.G., ed., Metamorphism and crustal evolution of the western United States: Englewood Cliffs, N. J., Prentice Hall, p. 681-713.

Taylor, J.R., 1982, An introduction to error analysis - The study of uncertainties in physical measurements: Mill Valley, California, University Science Books, 270 p.

Vikre, P.G., John, D.A., du Bray, E.A., and Fleck, R.J., in press, Gold-silver mining districts and alteration zones in the Miocene Bodie Hills volcanic field, California and Nevada: U.S. Geological Survey Scientific Investigations Report SIR-2015-5012, available at http://dx.doi.org/10.3133/sir20155012. 
Menlo Park Publishing Service Centers, California

Manuscript approved for publication January 23, 2015

Edited by Sarah Nagorsen

Design and Layout by Cory Hurd 

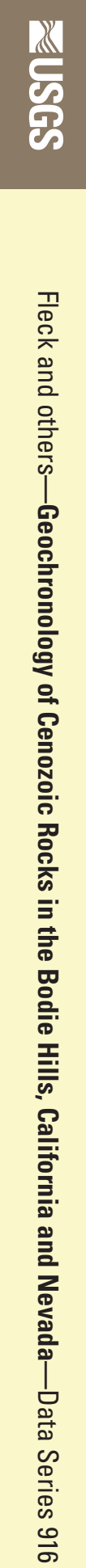

ISSN 2327-638X (online)

http://dx.doi.org/10.3133/ds916 